\title{
Hepatic Osteodystrophy-Molecular Mechanisms Proposed to Favor Its Development
}

\author{
Sabrina Ehnert ${ }^{1, *}$, Romina H. Aspera-Werz ${ }^{1}$, Marc Ruoß ${ }^{1}{ }^{\oplus}$, Steven Dooley ${ }^{2}$, Jan G. Hengstler ${ }^{3}$, \\ Silvio Nadalin ${ }^{4}$, Borna Relja ${ }^{5}$, Andreas Badke ${ }^{1}$ and Andreas K. Nussler ${ }^{1}$ \\ 1 Siegfried Weller Research Institute, Department of Trauma and Reconstructive Surgery, Eberhard Karls \\ University Tuebingen, BG Trauma Center Tuebingen, 72076 Tuebingen, Germany; \\ rominaaspera@hotmail.com (R.H.A.-W.); m.ruoss@hotmail.de (M.R.); abadke@bgu-tuebingen.de (A.B.); \\ andreas.nuessler@gmail.com (A.K.N.) \\ 2 Department of Medicine II, Molecular Hepatology, Medical Faculty Mannheim, University of Heidelberg, \\ 68167 Mannheim, Germany; steven.dooley@medma.uni-heidelberg.de \\ 3 IfADo-Leibniz Research Centre for Working Environment and Human Factors, Technical \\ University Dortmund, 44139 Dortmund, Germany; hengstler@ifado.de \\ 4 Department of General, Visceral and Transplant Surgery, University Hospital Tuebingen, 72076 Tuebingen, \\ Germany; silvio.nadalin@med.uni-tuebingen.de \\ 5 Department of Trauma, Hand and Reconstructive Surgery, University Hospital Frankfurt, Goethe University, \\ 60590 Frankfurt, Germany; info@bornarelja.com \\ * Correspondence: sabrina.ehnert@gmail.com; Tel.: +49-7071-606-1065
}

Received: 25 March 2019; Accepted: 22 May 2019; Published: 24 May 2019

check for updates

\begin{abstract}
Almost all patients with chronic liver diseases (CLD) show altered bone metabolism. Depending on the etiology, this manifests in a severe osteoporosis in up to $75 \%$ of the affected patients. Due to high prevalence, the generic term hepatic osteodystrophy (HOD) evolved, describing altered bone metabolism, decreased bone mineral density, and deterioration of bone structure in patients with CLD. Once developed, HOD is difficult to treat and increases the risk of fragility fractures. Existing fractures affect the quality of life and, more importantly, long-term prognosis of these patients, which presents with increased mortality. Thus, special care is required to support the healing process. However, for early diagnosis (reduce fracture risk) and development of adequate treatment strategies (support healing of existing fractures), it is essential to understand the underlying mechanisms that link disturbed liver function with this bone phenotype. In the present review, we summarize proposed molecular mechanisms favoring the development of HOD and compromising the healing of associated fractures, including alterations in vitamin D metabolism and action, disbalances in transforming growth factor beta (TGF- $\beta$ ) and bone morphogenetic protein (BMP) signaling with histone deacetylases (HDACs) as secondary regulators, as well as alterations in the receptor activator of nuclear factor kappa B ligand (RANKL)-osteoprotegerin (OPG) system mediated by sclerostin. Based on these mechanisms, we give an overview on the limitations of early diagnosis of HOD with established serum markers.
\end{abstract}

Keywords: bone metabolism; osteopenia; osteoporosis; liver disease; hepatic osteodystrophy; vitamin D metabolism; transforming growth factor beta (TGF- $\beta$ ); bone morphogenetic proteins (BMPs); histone deacetylases (HDACs); sclerostin

\section{Hepatic Osteodystrophy-Definition and Prevalence}

Current studies show that almost $75 \%$ of patients with chronic liver diseases (CLD) sooner or later suffer from severe osteoporosis [1,2]. Based on this high prevalence, the generic term hepatic osteodystrophy (HOD) evolved, defining alterations in bone mineral metabolism in patients with 
CLDs [3], eventually resulting in reduced bone mineral densities (BMD) and deterioration of bone structure, e.g., trabecular architecture or bone geometry. These alterations in bone structure increase the risk of fragility fractures in patients with HOD [4-8]. In case of a fracture, reconstruction of bone and handling of surrounding soft tissue represents a great challenge. Poor bone quality complicates classical fixation of fractures with screws and implants; despite continuous development of new products (screws, plates and implants, bone cements, etc.), the rate of delayed healings and non-unions remains high in these patients. Complicated wound healing and altered immune responses additionally raise the risk of infections. The resulting delay in convalescence affects not only quality of life, but also long-term prognosis of patients with CLD due to an increased mortality $[8,9]$.

The most widely studied group describes bone metabolic changes during viral liver diseases (hepatitis B virus (HBV) and hepatitis C virus (HCV)), which strongly depend on the reported disease stage. While on average $37.9 \%$ of patients with chronic viral hepatitis show changes in bone mineral metabolism, $80.3 \%$ of patients with viral cirrhosis develop a severe osteoporosis [10-12]. Metabolic bone disease associated with cholestatic liver diseases is less frequently reported. With an overall rate of $32.4 \%$ of patients with primary biliary cirrhosis (PBC) and $42.3 \%$ of patients with primary sclerosing cholangitis (PSC) being affected, this group has a high prevalence of developing an osteopenia or osteoporosis [1,13-18]. With alcoholism being an independent factor for the manifestation of an osteoporosis, overall $35.9 \%$ of patients suffering from alcoholic liver disease show altered bone metabolism and structure [12,19-21]. Less is known about non-alcoholic fatty liver disease (NAFLD) or non-alcoholic steatohepatitis (NASH). The mean prevalence of HOD in this patient group, often composed of children, is reported to be 45.7\% [22-24]. Approximately every second patient (49.3\%) with hemochromatosis shows altered bone structure (osteopenia or osteoporosis) [25-27]. The same holds for patients with Wilson disease, which have an average HOD rate of 49.3\% [28-31]. The described alterations in BMD significantly increase the risk and cumulative incidence of fractures in these patients, as reported by Tsai et al. investigating almost 4000 cirrhotic patients of mixed etiologies [6]. Table 1 gives an overview of available studies on HOD.

Regardless of the etiology, prevalence and severity (osteopenia or osteoporosis) of HOD positively correlates with duration and severity of the liver disease. Especially during end-stage liver disease and directly after orthotopic liver transplantation (OLT), higher fracture rates are reported, as the need for immunosuppressive drugs, e.g., glucocorticoids, may additionally harm the bone [48]. However, after successful OLT, when the use of glucocorticoids is reduced and liver function is reestablished, BMD frequently recovers [49-52].

Table 1. Rate of hepatic osteodystrophy (HOD) in chronic liver disease (CLD) of various etiologies. CI-confidence interval.

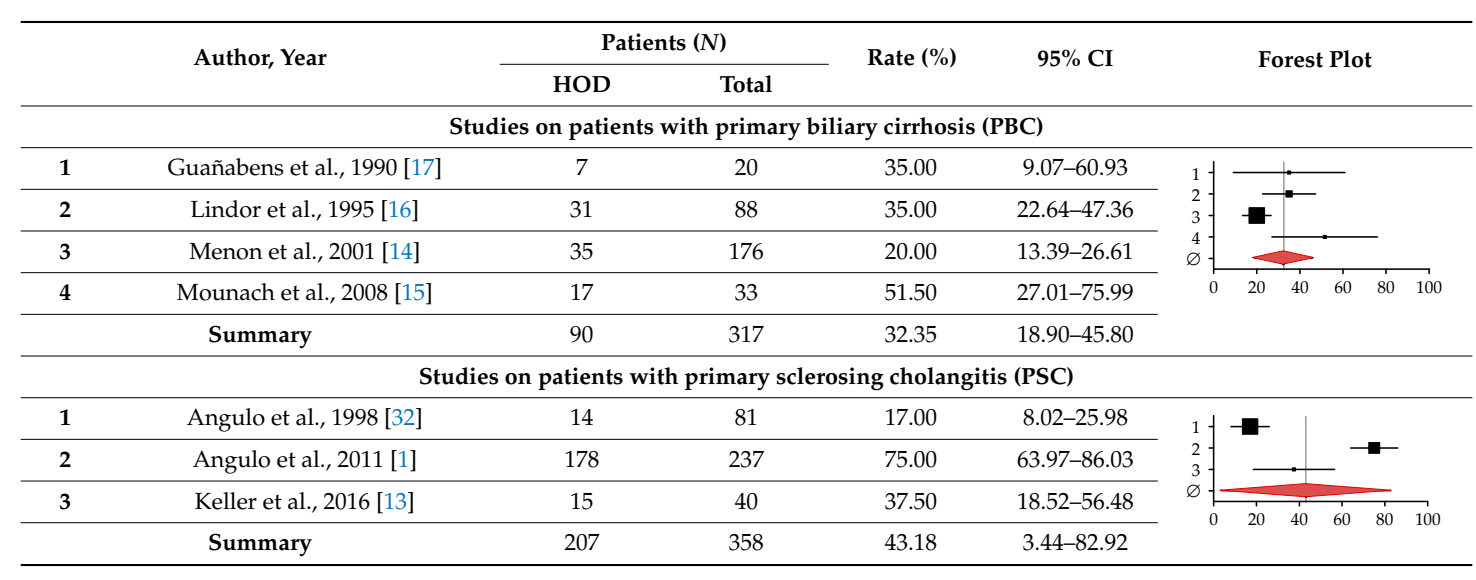


Table 1. Cont.

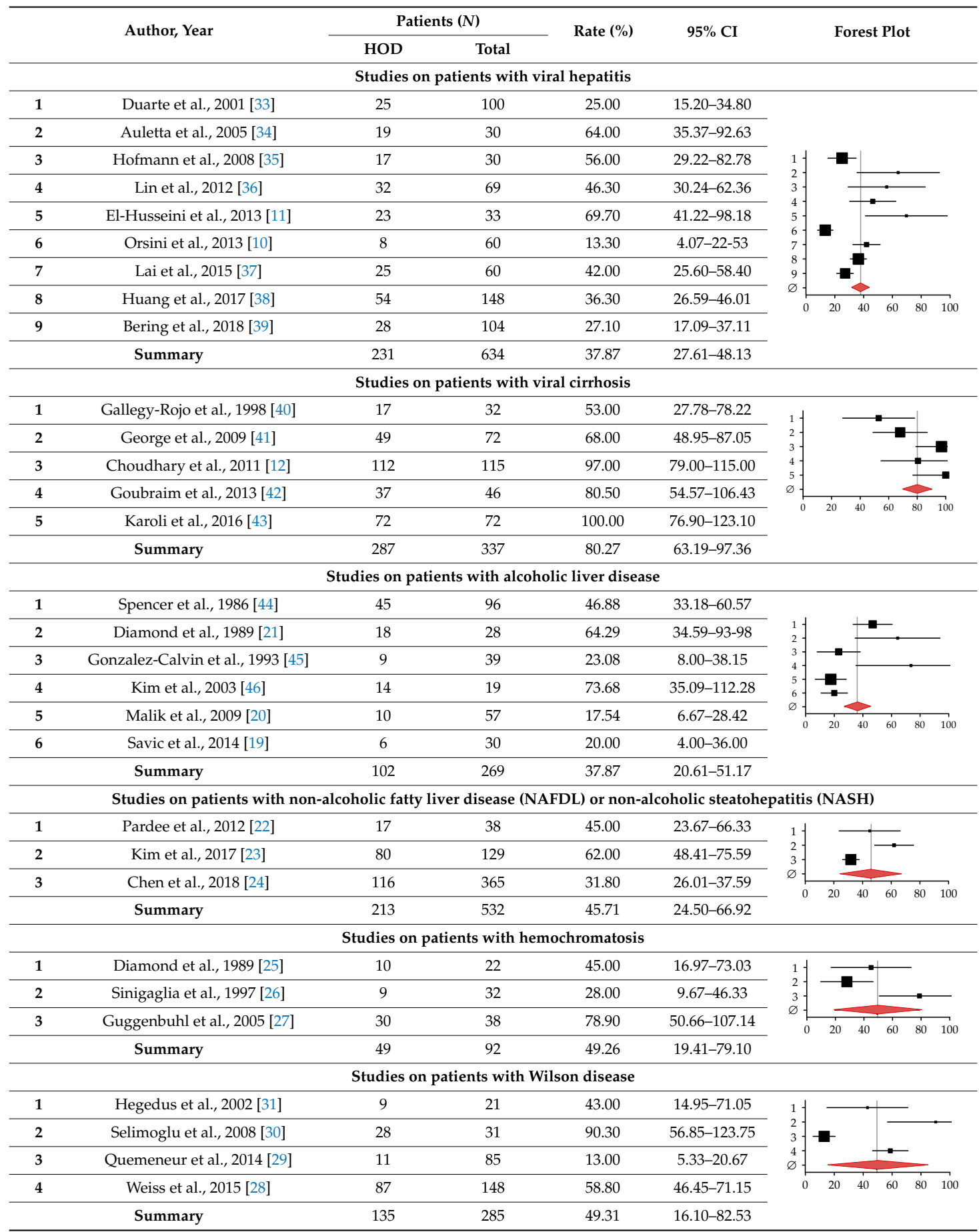

HOD occurrence rates (\%) were summarized with the random-effect model described in Neyeloff et al. [47] and visualized with the GraphPad Prism software. The research strategy is summarized in Appendix A.

\section{Limitations of Current Diagnostic Tools for HOD}

Although deleterious effects of CLD on bone metabolism and structure are frequently reported, early diagnosis of an altered bone metabolism represents a huge challenge. Radiologic changes in bone, preferably detected by dual-energy X-ray absorptiometry [53,54], often manifest only when bone metabolism is affected over a longer period of time and when changes in BMD, e.g., osteopenia and osteoporosis, are manifested. However, at the point when BMD is decreased, fracture risk is already 
increased [53,54]. Therefore, it is desirable to identify bone metabolic changes as early as possible in order to prevent or delay loss in BMD.

Osteoblasts and osteoclasts actively secrete factors into the blood. The detection of these serum markers is established as a marker for bone metabolism. In theory, detection of these serum markers could help identify changes in bone metabolism prior to manifestation of osteoporosis. However, in the context of CLD, the established serum markers for bone turnover allow only limited conclusions, as they often demonstrate the production and degradation of collagen (Figure 1).

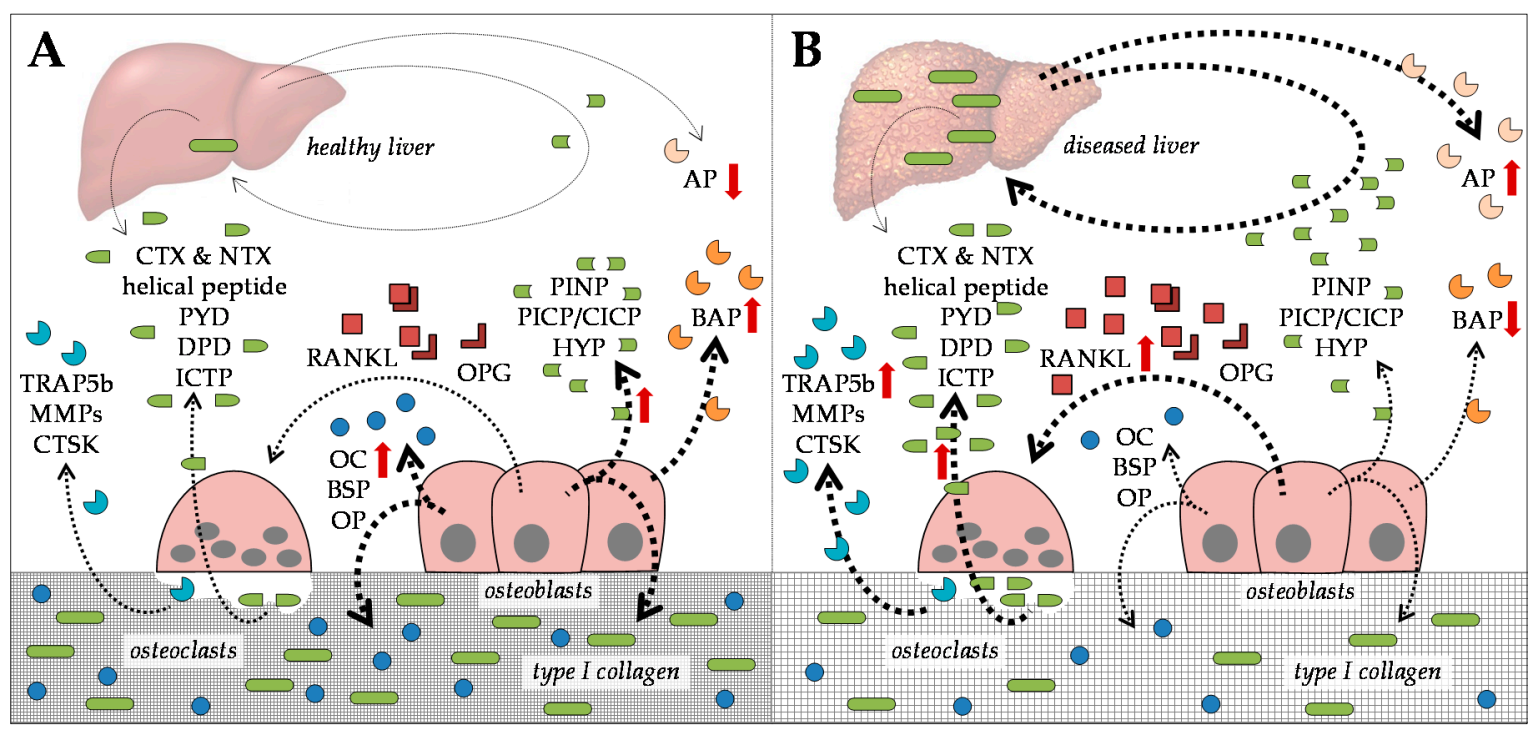

Figure 1. Established serum markers for bone turnover in the context of (A) healthy liver and (B) diseased liver. Bone resorption markers: tartrate-resistant acid phosphatase isoform 5b (TRAP5b), matrix metalloproteinase isoforms 2, 9, 13, and 14 (MMPs), cathepsin K (CTSK), pyridinolin (PYD), desoxypyridinolin (DPD), helical peptide, type I collagen cross-linked C-telopeptide (ICTP), and C-and $\mathrm{N}$-telopeptide crosslinks of type I collagen (CTX and NTX). Regulators of osteoclastogenesis: receptor activator of nuclear factor kappa B ligand (RANKL) and osteoprotegerin (OPG). Bone formation markers: osteocalcin (OC) bone sialoprotein (BSP), osteopontin (OP), bone-specific alkaline phosphatase (BAP), hydroxyprolin (HYP), and type I collagen $\mathrm{N}$ - and $\mathrm{C}$-terminal propeptides (PINP and PICP/CICP). Marker for liver/tissue damage: alkaline phosphatase (AP). Dotted arrows indicate expression. Red arrows indicate altered expression (up or down) in CLD.

\subsection{Serum Markers for Bone Formation}

Characteristic for collagen-I production are increased levels of hydroxyprolin (HYP), and type I collagen $\mathrm{N}$ - and C-terminal propeptides (PINP and PICP/CICP) in serum [55-58]. These markers are frequently used to assess bone formation. However, extensive matrix formation in the diseased liver is also known to increase serum levels of these markers and, thus, lead to false-positive results. Alternative markers for bone formation are increased serum levels of proteins secreted by osteoblasts. Available assays are bone-specific alkaline phosphatase (BAP) and osteocalcin (OC). Quantitative detection methods (ELISA, enzyme immunoassay (EIA), or radioimmunoassay (RIA)) for other proteins secreted by osteoblasts, e.g., bone sialoprotein (BSP), osteopontin (OP), receptor activator of nuclear factor kappa B ligand (RANKL), or osteoprotegerin (OPG), are available for experimental use, but still require validation for use in routine diagnostics. Furthermore, it remains to be elucidated whether these markers are affected by CLD. Taking, for example, alkaline phosphatase (AP), if not distinguished between the specific isoforms, it can be upregulated in patients' serum as a response to liver/tissue damage (AP) or during bone formation (BAP). 


\subsection{Serum Markers for Bone Degradation}

Degradation of collagen-I is accompanied by increased levels of pyridinolin (PYD), desoxypyridinolin (DPD), helical peptide, its cross-linked C-telopeptide (ICTP), and its C- and $\mathrm{N}$-telopeptide crosslinks (CTX $\alpha, \mathrm{CTX} \beta$, and NTX), all either circulating in the blood or secreted into the urine [55-58]. However, not only is excessive collagen formation characteristic during the development of fibrotic and cirrhotic liver diseases, but so is its remodeling. Therefore, excessive matrix degradation in the bone can easily be masked by the diseased liver [59], which limits the use of these markers. Alternative markers for bone resorption are increased serum levels of proteins secreted by osteoclasts; a validated assay is available for the quantification of tartrate-resistant acid phosphatase isoform $5 b$ (TRAP5b) serum levels. Similar to markers representing osteoblast function, quantitative detection methods for other markers of osteoclast function, e.g., cathepsin K (CTSK) or matrix metalloproteinase (MMP) isoforms 2, 9, 13, and 14, are available for experimental use, with the same restrictions; in addition to the lack of validation, it is likely that these markers are affected by CLD, e.g., as reported for MMPs [60,61].

The described limitations are one reason why HOD is often diagnosed only when changes in BMD became manifest in osteopenia or osteoporosis and the affected patients experience fragility fractures. Once developed, HOD is difficult to treat, and special care is required to support healing of existing fractures, as, in these patients, the process is commonly delayed and rich in complications, which in turn negatively affects the etiopathology of the associated liver disease [9]. For early diagnosis and to develop adequate treatment strategies, it is essential to understand the underlying mechanisms leading to HOD.

\section{Common Risk Factors Favoring the Development of HOD}

Several factors are associated with HOD, which are, thus, classified as possible risk factors for disease development. These factors include, among others, age, body mass index (BMI), duration and severity of the underlying liver disease, malnutrition or dietary deficiencies, overall low BMD with a history of fragility fractures, genetic predisposition, hormonal status, iron and copper accumulation, hyperbilirubinemia, alterations in vitamin status, and the effects of the used medication. Table 2 gives an overview on risk factors and proposed underlying mechanisms.

Table 2. Risk factors for bone loss in CLD. BMD—bone mineral densities; OLT—orthotopic liver transplantation; PTH—-parathyroid hormone; IGF-1—insulin-like growth factor 1; TNF—-tumor necrosis factor; IL-6-interleukin 6.

\begin{tabular}{|c|c|c|}
\hline Risk Factors & Proposed Mechanisms & Ref. \\
\hline Age & $\begin{array}{l}\text { Independent of CLD, age may cause disbalances in osteoclast and } \\
\text { osteoblast function. This is often associated with altered hormonal } \\
\text { status or epigenetic changes. }\end{array}$ & [62] \\
\hline Severity of liver damage & $\begin{array}{l}\text { HOD is correlated with severity of the liver disease; HOD is more } \\
\text { common in patients with end-stage liver disease and cirrhosis than } \\
\text { in patients with fibrosis or hepatitis. }\end{array}$ & [62] \\
\hline Low body mass index & $\begin{array}{l}\text { A low body mass index (BMI) often correlates with low BMD both } \\
\text { in healthy subjects and patients with CLD. A cut-off is usually set at } \\
\text { a BMI below } 19 \mathrm{~kg} / \mathrm{m}^{2}\end{array}$ & {$[63-65]$} \\
\hline Dietary deficiencies & $\begin{array}{l}\text { Malnutrition or dietary deficiencies frequently occur in patients } \\
\text { with CLD ( } 12 \% \text { of OLT patients), due to altered nutritional } \\
\text { requirements during ascites or other complications. }\end{array}$ & {$[66,67]$} \\
\hline Alcohol consumption & $\begin{array}{l}\text { Ethanol affects bone directly via a toxic effect on osteoblasts and } \\
\text { indirectly by altering PTH, vitamin D, testosterone, IGF-1, cytokines } \\
\text { (e.g., TNF or IL-6) and cortisol levels. }\end{array}$ & {$[68-71]$} \\
\hline
\end{tabular}


Table 2. Cont.

\begin{tabular}{|c|c|c|}
\hline Risk Factors & Proposed Mechanisms & Ref. \\
\hline Cigarette consumption & $\begin{array}{l}\text { Independent of CLD, smoking affects osteoblast and osteoclast } \\
\text { function, favoring the development of severe osteoporosis and } \\
\text { increasing the risk for fragility fractures. }\end{array}$ & [62] \\
\hline Physical exercise & $\begin{array}{l}\text { In patients with CLD, exercise levels are often reduced compared to } \\
\text { healthy individuals; thus, the bone receives less } \\
\text { mechanical stimulation. }\end{array}$ & {$[72,73]$} \\
\hline Muscle wasting & $\begin{array}{l}\text { Muscle wasting is very common in patients with CLD. When it } \\
\text { occurs independent of malnutrition, it may be an indicator for the } \\
\text { manifestation of HOD. }\end{array}$ & [74] \\
\hline \multirow{7}{*}{$\begin{array}{l}\text { Anomalies of vitamin } \mathrm{D} \text { and } \\
\text { calcium metabolism }\end{array}$} & $\begin{array}{l}\text { Early menopause and post-menopausal status additionally favors } \\
\text { bone loss in women. }\end{array}$ & {$[64]$} \\
\hline & $\begin{array}{l}\text { Hypogonadism may cause osteoporosis independent of CLD. } \\
\text { Parenchymal damage during CLD may cause hypogonadism due to } \\
\text { an altered hypothalamic-pituitary-thyroid function with reduced } \\
\text { release of gonadotrophins and primary gonadal failure. } \\
\text { CLD patients may have reduced vitamin D (VitD) absorption in } \\
\text { the gut. }\end{array}$ & \multirow{5}{*}[19,76-79]{} \\
\hline & $\begin{array}{l}\text { Enterohepatic circulation of VitD might be disturbed in patients } \\
\text { with CLD. }\end{array}$ & \\
\hline & $\begin{array}{l}\text { CLD patients frequently show impaired hepatic hydroxylation } \\
\text { of VitD. }\end{array}$ & \\
\hline & CLD patients may have increased urinary VitD excretion. & \\
\hline & $\begin{array}{l}\text { Reduced tissue sensitivity to VitD may contribute to the } \\
\text { development of HOD. }\end{array}$ & \\
\hline & $\begin{array}{c}\text { VitD deficiency may cause hyperparathyroidism which increases } \\
\text { bone turnover. }\end{array}$ & {$[80,81]$} \\
\hline Vitamin K deficiency & $\begin{array}{l}\text { Vitamin } \mathrm{K}(\mathrm{VitK}) \text { is required for the formation of osteocalcin and } \\
\text { osteonectin. VitK inhibits osteoclast viability, maturation, } \\
\text { and function. }\end{array}$ & [82-84] \\
\hline \multirow{4}{*}{ Growth hormones } & IGF-1 levels, which decrease during CLD, were linked to HOD. & {$[85,86]$} \\
\hline & $\begin{array}{l}\text { CLD is associated with a progressive increase in growth hormone } \\
\qquad(\mathrm{GH}) \text { resistance. }\end{array}$ & [87] \\
\hline & $\begin{array}{l}\text { Active transforming growth factor } \beta \text { (TGF- } \beta \text { ) is produced in } \\
\text { inflamed liver tissue. }\end{array}$ & {$[88,89]$} \\
\hline & $\begin{array}{c}\text { In response to damage, liver may produce bone morphogenetic } \\
\text { proteins (BMPs). }\end{array}$ & {$[90,91]$} \\
\hline Iron and copper & $\begin{array}{l}\text { Iron may directly affect osteoblast function. An excessive pituitary } \\
\text { iron deposition may favor the development of hypogonadism } \\
\text { independent of the CLD. }\end{array}$ & {$[27,92,93]$} \\
\hline Increased bilirubin & $\begin{array}{l}\text { Increased levels of unconjugated bilirubin (hyper-bilirubinemia) } \\
\text { were associated with a decreased osteoblast function, mediated } \\
\text { possibly via regulation of IGF-1. }\end{array}$ & {$[66,94-96]$} \\
\hline Genetic factors & $\begin{array}{c}\text { Genetic polymorphisms were described which may favor the } \\
\text { development of HOD, including genes encoding vitamin D } \\
\text { receptors or collagen type } 1 \mathrm{~A} 1 \text {. }\end{array}$ & [97-101] \\
\hline \multirow{5}{*}{ Medication } & $\begin{array}{l}\text { Corticosteroids affect bone structure by increasing osteoclasts } \\
\text { activity and by decreasing differentiation, recruitment, and lifespan } \\
\text { of osteoblasts. }\end{array}$ & [102] \\
\hline & $\begin{array}{l}\text { Calcineurin inhibitors are used in conjunction with corticosteroids; } \\
\text { thus, the independent effect of these agents on bone metabolism in } \\
\text { humans is uncertain. }\end{array}$ & [103] \\
\hline & $\begin{array}{l}\text { Antiviral agents, e.g., ribavirin, may directly affect osteoclast and } \\
\text { osteoblast function. }\end{array}$ & [104-106] \\
\hline & $\begin{array}{l}\text { Cholestyramine, a bile-acid sequestrant used to treat pruritus or } \\
\text { itching during CLD, was reported to adversely affect the intestinal } \\
\text { absorption of VitD. }\end{array}$ & [107] \\
\hline & $\begin{array}{l}\text { The effect of medication, e.g., diuretics, anticoagulants, and } \\
\text { chemotherapy, used in the treatment of advanced liver disease, on } \\
\text { bone metabolism in humans is uncertain. }\end{array}$ & \\
\hline
\end{tabular}

These mainly anamnestic factors define the risk of a patient with CLD to develop severe osteoporosis, but will not give any information on the actual disease status or the onset of the HOD. 
Furthermore, these factors provide only limited information on underlying molecular mechanisms, required for the identification of therapeutic targets and the development of treatment strategies.

Several of these factors, e.g., age, duration and severity of the underlying CLD, genetic predisposition, decreased BMD, or a familial history of fragility fractures, cannot be affected by treatment. Lifestyle-associated factors, e.g., physical exercise, dietary deficiencies, and consumption of alcohol and cigarettes, however, can be actively influenced by the patients. Thus, patients with CLD should be encouraged to change their lifestyle in order to reduce the risk and delay the development of a HOD. Factors involving medication, and altered hormonal or vitamin status can be influenced with the help of the attending physician. However, improved prevention will require a better understanding on the underlying molecular mechanisms.

\section{Alterations in Vitamin D and Calcium in Patients with CLD}

\subsection{Vitamin D Metabolism in Patients with CLD}

Lipophilic vitamin D (VitD) exists in two natural variants: VitD 2 (ergocalciferol—in plants) and $\mathrm{VitD}_{3}$ (cholecalciferol—in animals). In the human body, VitD is available mainly from cutaneous synthesis $\left(\mathrm{VitD}_{3}\right)$ and to a lesser extent from dietary uptake $\left(\mathrm{VitD}_{2}\right.$ and $\left.\mathrm{Vit}_{3}\right)$ [108]. During cutaneous synthesis, 7-dehydrocholesterol (7-DHC) converts to pre-VitD $\mathrm{V}_{3}$ and $\mathrm{VitD}_{3}$ under ultraviolet $\mathrm{B}$ (UVB) irradiation [109]. In the liver, 7-DHC is not only synthesized from cholesterol by cholesterol $7 \alpha$-hydroxylase (CYP7A1), but also degraded to cholesterol by 7 -dehydrocholesterol reductase (DHCR7). Mouse models for HOD show increased expression of DHCR7 in the diseased livers, which causes increased 7-DCH degradation during CLD [110,111]. This finding was confirmed by analysis of cirrhotic liver tissue of patients [110].

For circulation in the blood, VitD and its metabolites have to bind vitamin-D-binding protein GC (DBP), which is expressed in the liver. In mice, DBP expression decreases with progression of CLD $[110,111]$. Thus, it is assumed that circulation of VitD and its metabolites is impaired in patients with advanced liver disease.

In the healthy liver, VitD is hydroxylated by VitD 25-hydroxylase (CYP2R1) and sterol 27-hydroxylase (CYP27A1). Expression of both enzymes is reported to be decreased in fibrotic and cirrhotic livers [110,111]. Zhao et al. showed decreased CYP27A1 levels, but not decreased CYP2R1 levels in patients with liver cirrhosis [79]. The reaction product, calcidiol, also called 25-hydroxyvitamin $\mathrm{D}(25(\mathrm{OH}) \mathrm{D})$, is reported to be decreased during CLD [79,110,112]. In the kidneys, $25(\mathrm{OH}) \mathrm{D}$ is further hydroxylated to the biologically active calcitriol, also called 1,25-dihydroxyvitamin $\mathrm{D}\left(1,25(\mathrm{OH})_{2} \mathrm{D}\right)$, by 25-hydroxyvitamin D $1 \alpha$-hydroxylase (CYP27B1) [113,114]. Both 25(OH)D and 1,25(OH) $)_{2} \mathrm{D}$ may be further hydroxylated by 25-hydroxyvitamin D 24-hydroxylase (CYP24A1) in order to facilitate excretion of the products 24,25-dihydroxyvitamin $\mathrm{D}\left(24,25(\mathrm{OH})_{2} \mathrm{D}\right)$ and 1,24,25-trihydroxyvitamin $\mathrm{D}\left(1,24,25(\mathrm{OH})_{3} \mathrm{D}\right)$. Zhao et al. reported increased CYP24A1 levels in patients with liver cirrhosis, suggesting not only decreased VitD activation and circulation, but also increased VitD degradation in these patients [79]. For an overview, see Figure 2. 


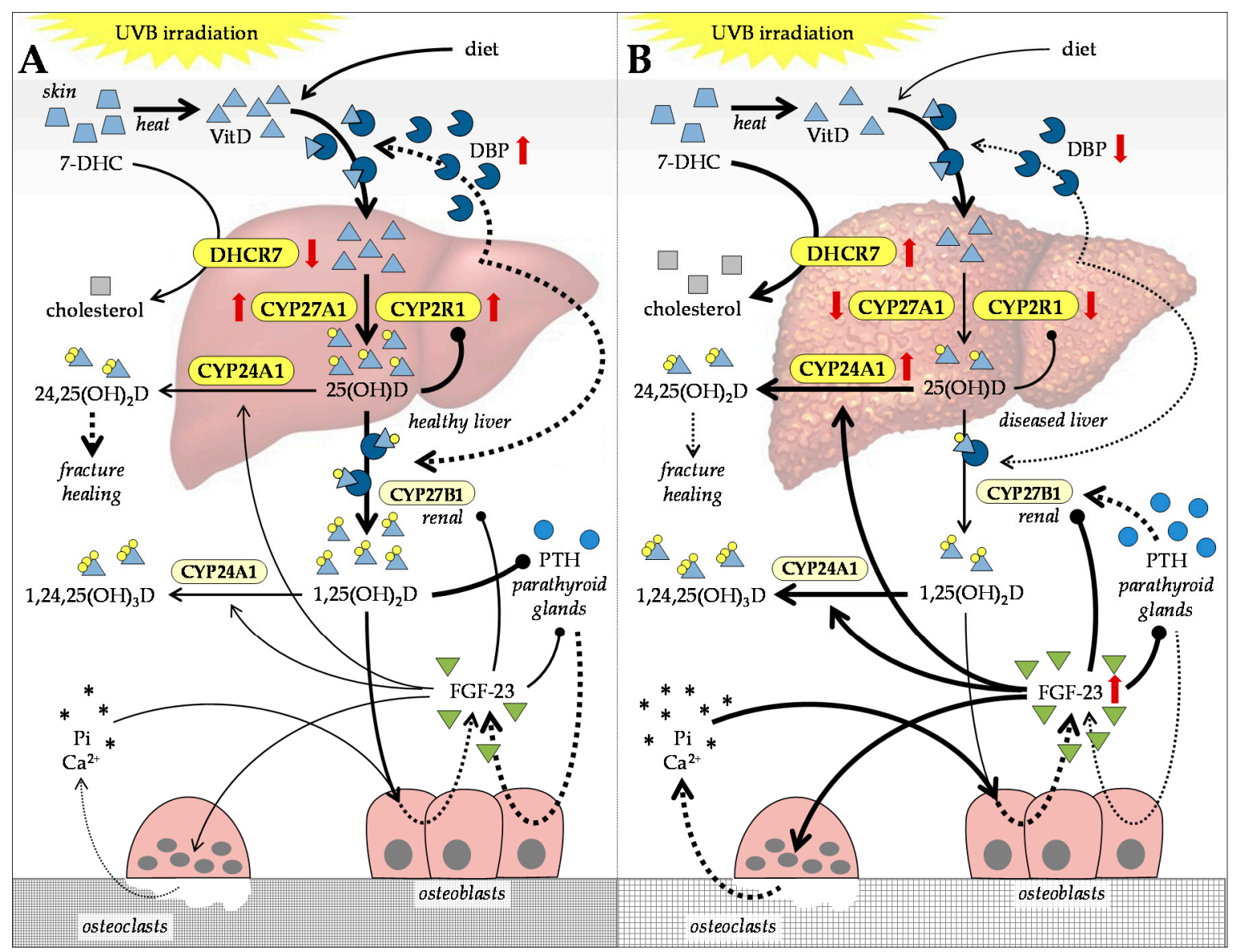

Figure 2. Vitamin D (VitD) metabolism in the context of (A) healthy liver and (B) diseased liver. In the presence of ultraviolet B (UVB) irradiation and heat, 7-dehydrocholesterol (7-DHC) is processed to VitD in the skin. VitD is sequentially hydroxylated in the liver and the kidneys to its metabolites calcidiol $(25(\mathrm{OH}) \mathrm{D})$, calcitriol $(1,25(\mathrm{OH}) \mathrm{D}), 24,25$-dihydroxyvitamin D $(24,25(\mathrm{OH}) \mathrm{D})$, and 1,24,25-trihydroxy-vitamin D (1,24,25(OH)D). Enzymes involved in VitD metabolism: 7-dehydrocholesterol reductase (DHCR7), vitamin D 25-hydroxylase (CYP2R1), sterol 27-hydroxylase (CYP27A1), 25-hydroxyvitamin D 1-hydroxylase (CYP27B1), and 25-hydroxyvitamin D 24-hydroxylase (CYP24A1). VitD and its metabolites bind to the vitamin-D-binding protein GC (DBP) for transport in the blood. Other regulators: calcium $\left(\mathrm{Ca}^{2+}\right)$, inorganic phosphate (Pi), fibroblast growth factor 23 (FGF-23), and parathyroid hormone (PTH). Dotted arrows indicate expression. Red arrows indicate altered expression (up or down) in CLD.

\subsection{VitD-Dependent Cellular Effects Affected in Patients with CLD}

To induce effects in target cells, $1,25(\mathrm{OH})_{2} \mathrm{D}$ needs to bind to the vitamin $\mathrm{D}$ receptor (VDR), which forms heterodimers with related receptors (e.g., the retinoid $\mathrm{X}$ receptor) in order to activate intracellular signaling cascades and to bind to vitamin D response elements (VDREs) $[115,116]$. So far, little is known about effects of CLD on the cellular sensitivity toward $1,25(\mathrm{OH})_{2} \mathrm{D}$, e.g., by regulating expression of VDR and related receptors, components that are strongly regulated by genetic polymorphisms [97-101]. In healthy subjects, $1,25(\mathrm{OH})_{2} \mathrm{D}$ supports intestinal absorption of calcium and phosphate [77]. In patients with CLD, lowered $1,25(\mathrm{OH})_{2} \mathrm{D}$ serum levels may, thus, impede intestinal absorption of inorganic phosphate (Pi) and calcium and, consequently, induce their release from bone matrix, favoring the loss of mineralized bone matrix [76].

Other cells highly responsive to $1,25(\mathrm{OH})_{2} \mathrm{D}$ are dendritic and monocytic cells [115]. Reduced activation of these cells may increase the susceptibility toward infections, as observed 
in the CALCITOP-study which shows an increased rate of wound infections in patients with low $1,25(\mathrm{OH})_{2} \mathrm{D}$ (but not $\left.25(\mathrm{OH}) \mathrm{D}\right)$ serum levels [117].

In bone-forming osteoblasts, $1,25(\mathrm{OH})_{2} \mathrm{D}$ enhances the expression of RANKL [118]. Upon binding to receptor activator of nuclear factor kappa B (RANK) on immune cells, RANKL induces their differentiation into bone-resorbing osteoclasts $[114,119]$. Nevertheless, in vivo, VitD and its metabolites inhibit osteoclastogenesis and, thus, are successfully used as supportive drugs to treat osteoporosis [120].

\subsection{Balancing VitD Levels in Patients with CLD}

First attempts were done to balance the described VitD deficiencies in order to improve the bone quality in patients with HOD. At first, oral VitD $\left(\mathrm{VitD}_{3}\right.$ or $\left.\mathrm{VitD}_{2}\right)$ supplementation appeared to improve the bone quality in mice [121] and seemed to delay the development of HOD in patients [122]. However, more recent studies showed no significant improvement of BMD in HOD despite improved $25(\mathrm{OH}) \mathrm{D}$ serum levels $[123,124]$. Based on the described alterations in VitD metabolism, the question raises if it is sufficient to supplement VitD or if supplementation of its metabolites is required. There is evidence that supplementation of $25(\mathrm{OH}) \mathrm{D}$ or $1,25(\mathrm{OH})_{2} \mathrm{D}$ is more efficient than supplementation of VitD [125]. Considering possible deficiencies in intestinal absorption and blood transport of VitD in patients with CLD, the route of application also has to be considered. In this case, it is advisable to first screen for serum levels of VitD and its metabolites to identify possible deficiencies [126,127].

Only a combination of oral VitD and bisphosphonates improved BMD in patients with CLD [128-131], suggesting that VitD supplementation alone is not sufficient to prevent or delay loss of BMD in these patients. Indeed, bisphosphonates represent the primary medical intervention to prevent bone loss in patients with CLD. However, as the review of Danford et al. framed, a benefit of this treatment in terms of fracture reduction remains to be shown in patients with CLD [132]. Therefore, current studies focus more on a better understanding of the molecular mechanisms that trigger the alterations in VitD and the linked calcium metabolism observed in patients with CLD.

\subsection{Feedback Mechanisms Regulating VitD Levels in Patients with CLD}

VitD metabolism is self-regulated through negative feedback mechanisms including calcium and Pi serum levels, fibroblast growth factor 23 (FGF-23), and parathyroid hormone (PTH) [119,133]. Increased $1,25(\mathrm{OH})_{2} \mathrm{D}$ and Pi serum levels may increase expression of FGF-23 in osteoblasts, which inhibits expression of PTH in the parathyroid glands $[134,135]$. It is proposed that binding of $1,25(\mathrm{OH})_{2} \mathrm{D}$ to VDR on the parathyroid glands can also directly decrease expression of PTH [136]. On the one hand, increased PTH levels are thought to induce expression of renal CYP27B1 and, thus, favor formation of $1,25(\mathrm{OH})_{2} \mathrm{D}$ [137]. This is one reason why PTH and PTH-related peptide analogs may be used as bone anabolic drugs $[138,139]$. For example, in an experimental model of biliary cirrhosis, administration of PTH 1-34 analog (teriparatide) was able prevent loss of bone mass and structure [140].

Reduced PTH levels on the other hand may increase FGF-23 expression in bone cells [134], which stimulates bone turnover by enhancing VitD metabolism both positively and negatively via inhibition of CYP27B1 and induction of CYP24A1 [97]. FGF-23 serum levels are reported to be increased in patients with CLD [141-143]. This may explain why increased PTH levels are negatively associated with secondary osteoporosis in these patients $[12,143,144]$ (Figure 2).

In addition to these described mechanisms, $1,25(\mathrm{OH})_{2} \mathrm{D}$ levels can be affected by estrogen, glucocorticoids, or calcitonin, which regulate expression of PTH either directly or indirectly. It was reported that estrogen-dependent regulation of PTH requires action of FGF-23 [145]. Glucocorticoids and calcitonin may increase PTH expression by lowering calcium serum levels. Glucocorticoid therapy may induce intestinal malabsorption and impaired renal re-absorption of calcium [146]. Calcitonin, primarily known as a pharmacologic inhibitor of bone resorption, lowers calcium levels by increasing its renal excretion $[147,148]$. However, in the same line of evidence, it was observed that decreased calcitonin levels, as observed in patients following thyroidectomy, 
are associated with decreased BMD [149-151]. In contrast to these $1,25(\mathrm{OH})_{2} \mathrm{D}$-dependent mechanisms, proteoglycan 4 may directly induce PTH expression [152].

Noteworthy, the non-classical actions of VitD, e.g., regulation of the renin-angiotensin system, may also play a relevant role in mortality and morbidity of patients with secondary osteoporosis $[153,154]$. This cascade leads to a sequential activation of angiotensin II, which likely has deleterious effects on blood pressure and the vasculature. Thus, decreased levels of $25(\mathrm{OH}) \mathrm{D}$ and $1,25(\mathrm{OH})_{2} \mathrm{D}$ are thought to predict hepatic and renal decompensation in these patients $[155,156]$.

\section{Alterations in Transforming Growth Factor- $\beta$ Superfamily in Patients with CLD}

\subsection{Regulation of Extracellular Matrix Proteins by Members of the Transforming Growth Factor- $\beta$ Superfamily}

In contrast to the progressively decreasing $25(\mathrm{OH}) \mathrm{D}$ and $1,25(\mathrm{OH})_{2} \mathrm{D}$ levels, CLD causes a permanent increase in active transforming growth factor- $\beta$ (TGF- $\beta$ ) [157]. Its expression is induced in the context of the fibrogenic response in the liver. By activating hepatic stellate cells and inducing extracellular matrix (ECM) production, TGF- $\beta$ triggers fibrotic alterations in the liver in CLD of many etiologies [158]. The active TGF- $\beta$ is then distributed in the entire body via the blood stream, which may affect bone metabolism and fracture healing.

In healthy subjects, TGF- $\beta$ is by far the most abundant cytokine in bone [159]. TGF- $\beta$ is secreted in its latent form by osteoblasts and osteoclasts. Upon secretion, the latent TGF- $\beta$ is incorporated into the bone matrix $[160,161]$. During bone resorption or fracture, osteoclasts activate TGF- $\beta$ in their resorption lacuna via proteolytic and acidic hydrolysis $[162,163]$. The released active TGF- $\beta$ in bone then functions as a chemoattractant and growth factor for mesenchymal stem/stromal cells (MSCs) and osteoprogenitor cells, which express a large variety of high affinity TGF- $\beta$ family receptors. Of the three TGF- $\beta$ isoforms (TGF- $\left.\beta_{1-3}\right)$, TGF- $\beta_{1}$ has the strongest chemotactic effect toward cells of the osteoblastic lineage in human. It is thought to regulate not only migration and proliferation, but also to induce expression of ECM genes, e.g., collagen, fibronectin, and the associated integrin receptors in these cells [161,164-167]. Less is known about TGF- $\beta_{2}$, which, upon over-expression in mice bones, stimulates bone metabolism, eventually causing an osteoporotic phenotype [168]. TGF- $\beta_{3}$ is thought to induce MSC differentiation toward the chondrogenic lineage, an essential step in endochondral ossification as observed in the developing skeleton or in the fracture callus during long bone repair [169]. Research focusing mainly on short-term effects of TGF- $\beta$ on bone cells undoubtedly shows the importance of TGF- $\beta$ in the initiation of fracture healing [170]. These local and dose-dependent effects are well described in a dog model, applying TGF- $\beta$ ectopically in order to support mechanical fixation, bone ingrowth, and gap bone formation of unloaded implants [171]. However, patients with CLD frequently have chronically elevated TGF- $\beta$ levels. This may disguise the described positive effects of TGF- $\beta$ in bone, which require tightly regulated local gradients of the cytokine.

Chronically increased levels of active TGF- $\beta$, as observed during CLD, alter the composition of the ECM matrix, thus affecting bone flexibility $[172,173]$. By shifting the ECM matrix toward fibronectin, release of cytokines (including TGF- $\beta$ ) from the bone matrix is induced, which in turn favors osteoclast formation and activity $[164,174]$. TGF- $\beta$ signaling induces expression of native fibronectin and its splice variant, termed oncofetal fibronectin in CLD [175-177]. This O-glycosylated form of fibronectin directly interferes with bone formation and, thus, may contribute to the development of HOD [176]. Similarly, TGF- $\beta$ induces expression of vimentin via the activating transcription factor ATF4, which may suppress maturation of osteoprogenitor cells and related osteocalcin expression [172] and, thus, contribute to the development of HOD. In addition, chronically elevated TGF- $\beta_{1}$ levels block osteoblast maturation by interfering with bone morphogenetic protein (BMP) signaling [178]. From the members of the BMP family, BMP2, 4, 7, and 9 show osteo-inductive properties. Interestingly, BMP7 and 9 are expressed in liver cells as a response to damage, initially to suppress pro-fibrotic TGF- $\beta$ effects $[90,91]$. While BMPs may suppress TGF- $\beta$ effects in the liver [91,179], the contrary is the case in bone [178]. 
Therefore, increased levels of BMPs may not compensate for the inhibitory effects of TGF- $\beta$ in bone (Figure 3).

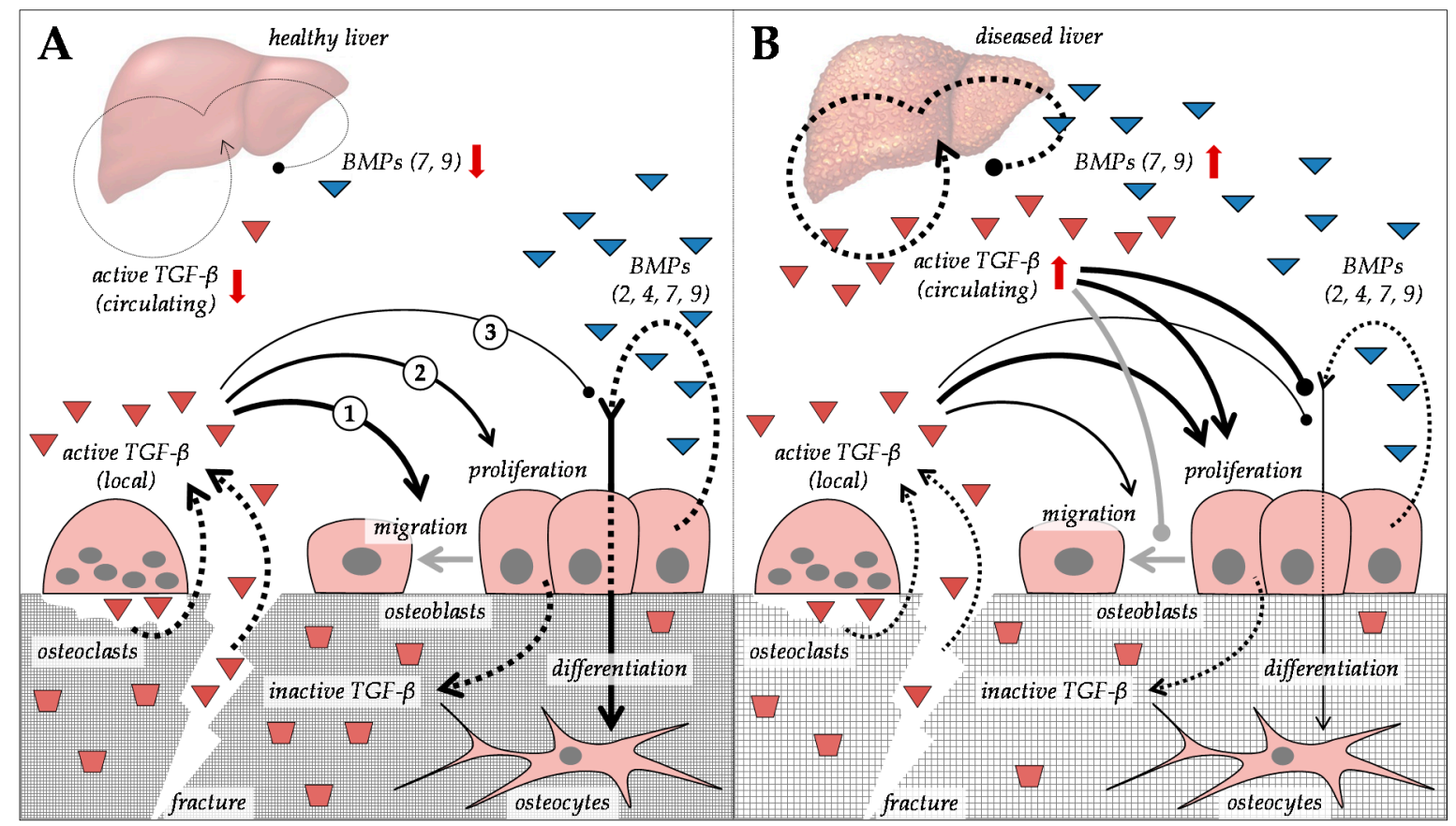

Figure 3. Effects of transforming growth factor- $\beta$ (TGF- $\beta$ ) and bone morphogenetic protein (BMP) on bone in the context of $(\mathbf{A})$ healthy liver and $(\mathbf{B})$ diseased liver. Dotted arrows indicate expression. Red arrows indicate altered expression (up or down) in CLD.

\subsection{Regulation of TGF- $\beta$ and BMP Signaling}

TGF- $\beta$ and BMP both transduce their signals by binding (usually as homodimers) to a tetrameric receptor complex on the cell surface, consisting of two types of serine/threonine kinase receptors $[180,181]$. In human, seven type I receptors (termed activin receptor-like kinase (Alk)-1 through 7) and five type II receptors were identified, which have to comply with more than 30 ligands of the TGF- $\beta$ superfamily. This implies that individual receptors have to bind more than one ligand [182]. Furthermore, cell-type-dependent expression patterns of the receptors may explain the above-described cell-type-dependent differences in ligand response. Upon ligand binding, intracellular signal transduction occurs both canonically (dependent on Smad transcription factors) and non-canonically (Smad-independent/mitogen-activated protein kinase (MAPK) signaling). In bone cells, canonical TGF- $\beta$ signaling is mediated via Alk4-, 5-, or 7-dependent phosphorylation of Smad2/3, while canonical BMP (BMP2, 4, 7, and 9) signaling is mediated via Alk1-, 2-, 3-, or 6-dependent phosphorylation of Smad1/5/8. Complex formation with Smad4 allows the activated transcription factor complexes to translocate into the nucleus and, thus, regulate target gene expression [183]. Canonical signaling cascades are controlled by various regulatory mechanisms, including among others inhibition by intra- and extracellular inhibitors, regulation of gene expression, post-transcriptional modifications, and intracellular trafficking [184]. Expression of some of the regulatory proteins is initiated by the signaling itself, as an internal feedback mechanism, e.g., the inhibitory Smad6 and 7, Smad ubiquitination regulatory factors (Smurfs)-1 and 2, Smad anchor for receptor activation (SARA), BMP and activin receptor membrane bound inhibitor (BAMBI), Noggin, v-ski sarcoma viral oncogene homolog (Ski), and Ski-like oncogene (SnoN) [178]. Membrane bound BAMBI and soluble Noggin inhibit TGF- $\beta$ /BMP signaling by competing with the type I receptor for ligand binding $[181,185]$. The Smad co-factor SARA enhances TGF- $\beta$ signaling via direct interaction with Smad2, favoring its recruitment to the TGF- $\beta$ receptor [181]. Intracellularly, Smad6 specifically interferes with the Smad1/5/8 pathway, while Smad7 is able to blunt both Smad1/5/8- and Smad2/3-mediated signal transduction. 
Mechanistically, inhibitory Smads interact with TGF- $\beta$ receptors and Smad proteins in order to facilitate their ubiquitination and degradation with the help of the E3 ubiquitin ligases Smurf-1 and 2 [181]. Ski and SnoN belong to the negative regulators of Smad transcriptional function, antagonizing TGF- $\beta$ signaling primarily through transcriptional modulation via recruitment of nuclear transcriptional co-repressors and histone deacetylases (HDACs) [181].

\subsection{HDACs as Possible Secondary Regulators for HOD}

As described above, disbalanced TGF- $\beta$ and BMP signaling may favor development of HOD. One proposed mechanism is via recruitment and activation of HDACs [178]. Although numerous HDACs are expressed and active in bone cells, their tight regulation is critical, as different HDACs exert variant effects on the different cell types (Table 3). For example, expression of HDACs 2, 4, 5, 6, and 7 is normally increased during osteogenesis [186-191], and deletion/inhibition of HDACs 2, 3, 4, 7, and 5/9 is associated with decreased BMD or altered bone structure [192-204]. A genome-wide association study even identified HDAC5 as one of 20 loci associated with osteoporosis [205], representing an independent risk factor for the development of HOD. These reports give evidence that HDACs are crucial regulators of bone metabolism. The most commonly described mechanism how HDACs $(1,2,3$, $4,5,6,7$, and 8) regulate bone metabolism is their direct interaction or interference with transcription factors involved in osteogenic differentiation, e.g., Runx2, p300, Mef2, Mef2c, NFATc1, Zfp521, or TCF. This interaction usually represses their transcriptional activity and, thus, decreases expression of osteogenic marker genes, e.g., collagen or osteocalcin [187,190,191,206-215]. In addition to direct interaction with Runx2, HDACs 4 and 5 may further decrease transcriptional activity of Runx2 via post-translational modifications, which favors its degradation $[187,210]$. Resulting altered expression of target genes, e.g., OPG, RANKL, or Wnt, may affect terminal differentiation of bone cells.

Expression of HDACs is strongly regulated by factors circulating in the blood of patients with CLD. For example, in differentiating human osteoblasts, TGF- $\beta$ induces expression of HDACs 1, 2, 3, 6, and 11 and blocks expression of HDAC9 $[188,189]$. On the one hand, a TGF- $\beta$-dependent decrease in HDAC9 keeps MSCs and osteoblasts in a proliferative stage, thus preventing their maturation [189]. TGF- $\beta$-dependent increase in HDAC6 activity is associated with structural deterioration of primary cilia, the mechanosensors of osteoblasts [188]. Thus, increased active TGF- $\beta$ levels in the blood of patients with CLD may affect the response of osteoblasts toward mechanical stimulation. Altering primary cilia structure not only affects sensing of mechanical stimuli, but also alters signal transduction cascades, including $\mathrm{Ca}^{2+}$, TGF- $\beta$, Wnt, and mammalian target of rapamycin (mTOR) [216-218]. HDAC6, being induced by hypoxia and oxidative stress [192], may promote transcriptional activity of hypoxia-inducible factor $\alpha$ (Hif-1 $\alpha)$ early after fracture [219]. 
Table 3. Proposed regulatory roles of histone deacetylases (HDACs) in bone metabolism. MSC—mesenchymal stem/stromal cells; OPG—osteoprotegerin; FGF-21—fibroblast growth factor 21; MMP — matrix metalloproteinase; Hif- $1 \alpha$-hypoxia-inducible factor $\alpha$; RANKL—receptor activator of nuclear factor kappa B ligand; PPAR $\gamma$ - peroxisome proliferator-activated receptor $\gamma$;

\begin{tabular}{|c|c|c|c|}
\hline \multicolumn{2}{|c|}{ HDACs } & \multirow{2}{*}{$\begin{array}{c}\text { Proposed Mechanisms } \\
\text { Expression is decreased during osteogenic differentiation. }\end{array}$} & \multirow{2}{*}{$\begin{array}{c}\text { References } \\
{[188-190,214,228]}\end{array}$} \\
\hline \multirow{9}{*}{ 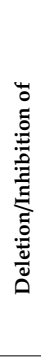 } & 1,9 & & \\
\hline & 9 & Expression is blocked by TGF- $\beta$ signaling. & {$[188,189]$} \\
\hline & 4,9 & Expression is regulated by microRNAs (miR-17, miR-29b, miR-188). & [229-231] \\
\hline & 1,6 & Associated with improved skeletal phenotypes. & {$[228,232-234]$} \\
\hline & $2-5,7-9$ & Associated with impaired skeletal phenotypes. & [192-204] \\
\hline & 1,7 & Induce expression of osteoblastic genes, e.g., TNAP. & {$[191,235]$} \\
\hline & 3 & Drives MSC differentiation towards adipogenic lineage. & [198-201] \\
\hline & 3,4 & Favor expression of OPG, FGF-21, MMP3, MMP10, and MMP13. & {$[197,208,223,224,236]$} \\
\hline & $4,5,9-11$ & $\begin{array}{l}\text { Increase osteoclast size and demineralization activity, together with } \\
\text { increased expression of c-Fos, NFATc1, and Cathepsin K. }\end{array}$ & [237] \\
\hline \multirow{24}{*}{ 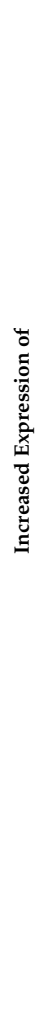 } & $2,4-7$ & Increased during osteogenic differentiation. & [186-191] \\
\hline & $1-3,6,11$ & Induced by TGF- $\beta$ signaling. & {$[188-190,214,228]$} \\
\hline & 1 & Induced by mechanical stimulation. & [228] \\
\hline & 6 & Induced by hypoxia and oxidative stress. & [192] \\
\hline & 4,5 & Associated with impaired skeletal phenotypes. & {$[186,238]$} \\
\hline & 5 & Polymorphisms are associated with decreased BMD. & [205] \\
\hline & 5,6 & Suppress expression of transcription factors, e.g., Runx2 or osterix. & {$[210,220]$} \\
\hline & $1-8$ & $\begin{array}{l}\text { Repress transcriptional activity of, e.g., Runx2, p300, Mef2, Mef2c, } \\
\text { NFATc1, Zfp521, or TCF by direct interaction/binding. }\end{array}$ & {$[187,190,191,206-215]$} \\
\hline & 4,5 & Deacetylate Runx2, affecting its transcriptional activity. & {$[187,210]$} \\
\hline & 4,5 & Deacetylate Runx2, promoting its degradation. & {$[187,210]$} \\
\hline & 4,9 & Expression is regulated by miRNAs (miR-17, miR-29b, miR-188). & [229-231] \\
\hline & 4 & Its cytoplasmic-nuclear shuttling is regulated by mechanical load. & [194] \\
\hline & 2 & $\begin{array}{l}\text { Regulates proliferation, oxidative stress, and apoptosis by (binding) } \\
\text { regulating transcriptional activity of Nrf2/ARE. }\end{array}$ & {$[239,240]$} \\
\hline & 4 & Interaction with PTH regulates expression of genes, e.g., MMP13. & [225-227] \\
\hline & 6 & Promotes Hif- $1 \alpha$ transcriptional activity. & [219] \\
\hline & 2 & Favors osteoclastogenesis via Akt-mediated suppression of FoxO1. & [241] \\
\hline & 2,6 & $\begin{array}{l}\text { Interact with glucocorticoid receptor to regulate inflammation and } \\
\text { expression of genes, e.g., osteocalcin or collagen } \\
\text { during osteogenesis. }\end{array}$ & {$[220-222,242]$} \\
\hline & 3 & Required for bone maintenance during aging. & [243] \\
\hline & 3 & Represses activity of MMP13, proposed regulation via ERK1/2. & {$[223,224]$} \\
\hline & 5 & Regulates PTH-driven sclerostin expression in osteocytes via Mef2. & [207] \\
\hline & 6 & $\begin{array}{l}\text { Affects structural integrity of primary cilia, the mechanosensory } \\
\text { organelle on osteoblasts, which regulates signaling pathways. }\end{array}$ & [188] \\
\hline & $3,7,9$ & Regulate osteoclastogenesis via RANKL, Wnt, and PPAR $\gamma$. & [244-247] \\
\hline & $1,3,7$ & Regulate inflammation, proposedly involving STAT and NF-кB. & {$[224,234,248]$} \\
\hline & 9 & Promotes proliferation of osteogenic cells, interacting with p53. & {$[189,249]$} \\
\hline
\end{tabular}

Both HDAC6 and HDAC2 may interact with the glucocorticoid receptor in order to regulate expression of osteogenic genes, e.g., osteocalcin, collagen, or osterix, during osteogenesis, a strongly dose-dependent effect [220-222]. This way, increased glucocorticoid signaling, as expected under glucocorticoid medication [102], may contribute to impaired osteogenesis in relevant patients.

Decreased levels of HDACs 3 and 4 are associated with increased bone catabolism, proposedly mediated via increased expression of FGF-21 and MMPs (e.g., MMP3, MMP10, and MMP13) [196,223-225]. Interaction with PTH, often increased during CLD, may alter HDAC4-dependent expression of these genes [225-227]. Thus, it is feasible that CLD affects bone catabolic effects mediated by HDAC4. By interacting with HDAC5 and Mef2, PTH may increase expression of sclerostin in osteocytes [207], thus preventing formation of mineralized bone matrix.

Diverse small chemical inhibitors for HDAC activity are available; however, their use to support bone metabolism has to be critically discussed, as they were mainly approved for treatment of patients with cancer [250-253]. Their use is associated with severe adverse effects that may not legitimate their application to delay or prevent the development of HOD. Identification of the actual key regulators 
(HDAC isoforms) and better understanding of the underlying molecular mechanisms will help choose more specific inhibitors or activators with fewer side effects.

\section{Sclerostin-A New Player in the Game?}

Sclerostin was first identified as relevant for bone formation in studies investigating patients with sclerosteosis and van Buchem disease. In these patients, sclerosing bone conditions are associated with functional loss mutations of the gene (SOST) encoding sclerostin [254-256].

For a long time, sclerostin was thought to be exclusively expressed in osteocytes as a negative feedback inhibitor to prevent excessive bone formation. Sclerostin was first thought to inhibit BMP-dependent Smad signaling by competing with BMP for receptor binding [257]. However, more recent work revealed that sclerostin, similar to dickkopf 1 (DKK1) and 2 (DKK2), represses Smad1/5/8 signaling indirectly via inhibition of the Wnt signaling pathway, which is required for nuclear translocation of Smad1/5/8 [258].

Expression of the key regulators of osteoclastogenesis (macrophage colony-stimulating factor (M-CSF), RANKL, and OPG) is regulated by the Wnt signaling cascade. Attenuation of Wnt/BMP signaling by sclerostin affects expression of these genes $[259,260]$. The resulting imbalances in the RANKL-OPG system may lead to alterations in BMD due to altered activity of osteoclasts. RANKL, by binding to its high-affinity receptor (RANK) located on the surface of monocytes and pre-osteoclasts, drives their differentiation toward mature osteoclasts with bone-resorbing activity [174]. Its secreted inhibitor OPG is produced by the bone and the liver in healthy subjects, in order to inhibit osteoclast differentiation [261]. There are reports showing altered levels of OPG and/or RANKL in patients with CLD [262-264]. However, a correlation between decreased BMD in patients with end-stage liver disease was observed only with serum OPG or RANKL levels [265,266] (Figure 4D,E). 


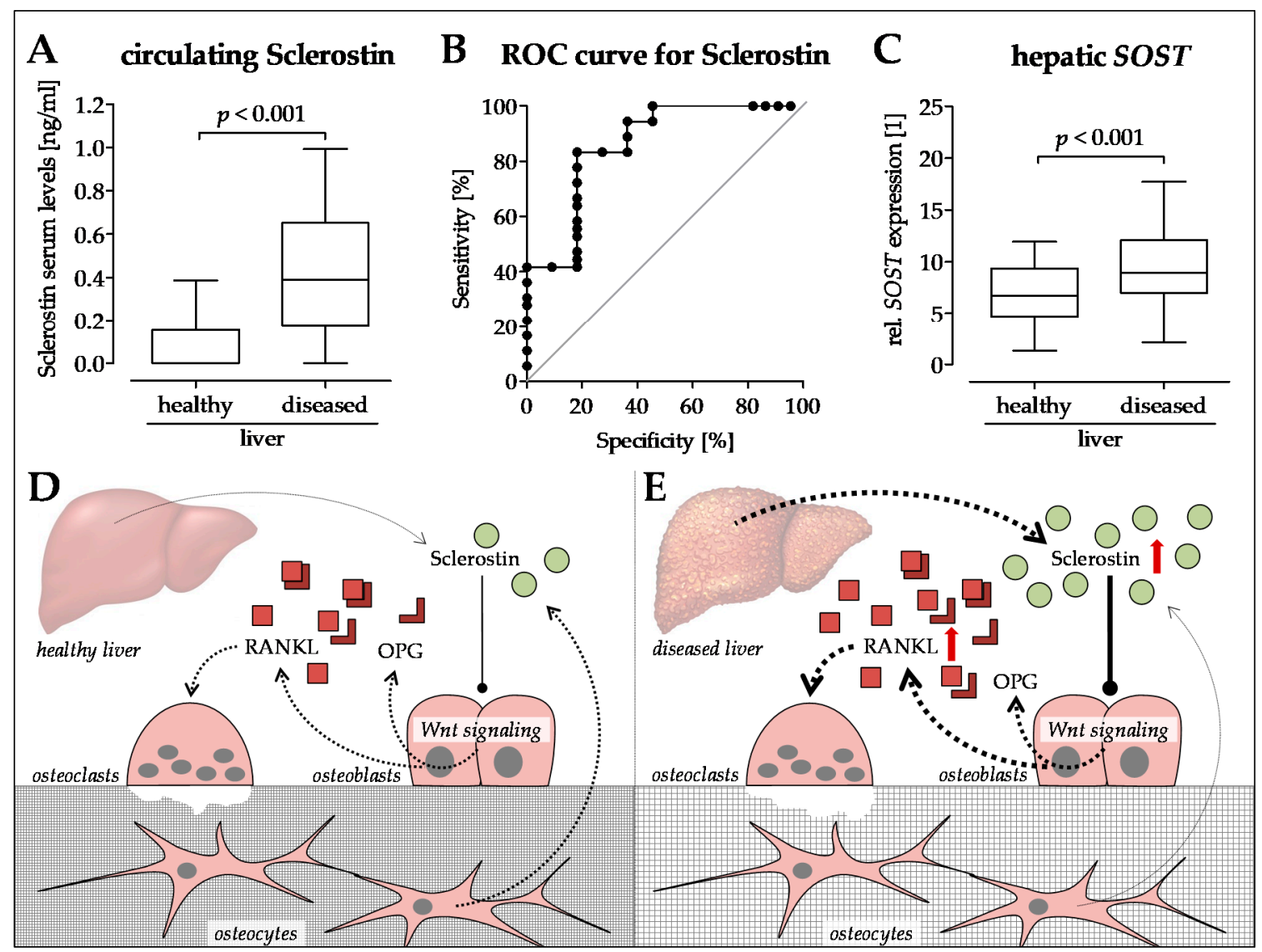

Figure 4. Sclerostin as a possible regulator in the development of hepatic osteodystrophy (HOD). (A) Sclerostin serum levels were determined with the help of Sclerostin TECO ${ }^{\circledR}$ ELISA (TECOmedical group, Neufahrn, Germany) in patients with healthy and diseased livers. (B) Receiver operating characteristic (ROC) curve with sclerostin as a marker for HOD. (C) Expression of SOST in healthy and diseased liver tissues. $N \geq 22, n=2$; statistical comparison with the Mann-Whitney U-test. Proposed regulatory mechanisms in the context of (D) healthy and (E) diseased liver. Dotted arrows indicate expression. Red arrows indicate altered expression (up or down) in CLD.

In case of increased RANKL levels, therapy with anti-RANKL antibody (Denosumab, Amgen, Thousand Oaks, CA, USA), known under the trade names Prolia and Xgeva, may be an interesting option for these patients $[267,268]$. Interestingly, in a case report, even amelioration of hepatitis is described when this treatment was applied to a woman with growth hormone deficiency [269].

We identified increased sclerostin serum levels in patients with CLD (liver cirrhosis) (Figure 4A), which is in line with reports on patients with alcoholic and non-alcoholic liver disease [270-272]. The work of Guañabens and colleagues suggests that increased sclerostin in diseased liver (PBC) is mainly located in the bile ducts [273]. In our patients, sclerostin serum levels were correlated with decreased BMD (Figure 4B). Thus, treatment with the anti-sclerostin antibody (Romosozumab-AMG 785 , UCB, Union Chimique Belge, Brussels, Belgium) may be an interesting strategy to fight osteoporosis in patients with HOD $[274,275]$. Interestingly, sclerostin was strongly expressed in liver tissues of these patients (Figure 4C). Possible effects on liver disease, however, are yet to be investigated. Circulating via the blood stream, increased sclerostin levels may affect bone metabolism and, thus, contribute to the development of HOD.

\section{Summary and Outlook}

Studies reporting bone changes in patients with CLD suggest that approximately $75 \%$ of patients with CLD will develop HOD. Once developed, HOD is difficult to treat [9]. When changes in BMD 
and bone structure are manifest, patients are at high risk of developing fragility fracture [7]. In case of a fracture, convalescence is prolonged and rich in complications, which in turn negatively affects quality of life and long-term prognosis of these patients [9].

We here demonstrate the challenge toward an early diagnosis of HOD, as many established serum markers for bone turnover are adversely regulated by the diseased liver. We describe how acquisition of anamnestic data may predict the risk of a patient to develop HOD, and how, using this knowledge, patients may delay the development of HOD by modifying lifestyle habits or medication in consultation with the attending physician.

The development of treatment strategies to prevent, delay, or reverse the development of HOD, however, requires deeper understanding of the underlying molecular mechanisms. We summarize current knowledge on potential mechanisms and how they qualify as therapeutic targets. These include alterations in VitD metabolism and action, disbalances in TGF- $\beta$ and BMP signaling, altered expression and action of HDACs, and sclerostin as a regulator of the RANKL-OPG system. MSCs, osteoblasts, osteocytes, and osteoclasts, via altering their function, all represent interesting targets for the development of therapeutic strategies for patients with HOD. However, the diversity of the described risk factors and possible molecular mechanisms emphasize that HOD is a multifactorial disease that cannot easily be prevented via a simple supplementation of just a single factor, but instead may require a combinatory therapy.

Author Contributions: Conceptualization, S.E. and A.K.N.; formal analysis, S.E.; investigation, S.E.; resources, S.D., J.G.H., S.N., and A.K.N.; writing—original draft preparation, S.E. and A.K.N.; writing-review and editing, R.H.A.-W., M.R., S.D., J.G.H., S.N., B.R., A.B., and A.K.N.; visualization, S.E.

Conflicts of Interest: The authors declare no conflicts of interest.

$\begin{array}{ll}\text { Abbreviations } & \\ \text { 1,24,25(OH)D } & \text { 1,24,25-trihydroxyvitamin D } \\ \text { 1,25(OH)D } & \text { 1,25-dihydroxyvitamin D, also called calcitriol } \\ \text { 24,25(OH)D } & \text { 24,25-dihydroxyvitamin D } \\ \text { 25(OH)D } & \text { 25-hydroxyvitamin D, also called calcidiol } \\ \text { 7-DHC } & \text { 7-dehydrocholesterol } \\ \text { BAMBI } & \text { BMP and activin receptor membrane bound inhibitor } \\ \text { BAP } & \text { bone-specific alkaline phosphatase } \\ \text { BMD } & \text { bone mineral density } \\ \text { BMI } & \text { body mass index } \\ \text { BMP } & \text { bone morphogenetic protein } \\ \text { BSP } & \text { bone sialoprotein } \\ \text { CLD } & \text { chronic liver disease } \\ \text { CTSK } & \text { cathepsin K } \\ \text { CTX } & \text { C-telopeptide crosslinks of type I collagen } \\ \text { CYP24A1 } & \text { 25-hydroxyvitamin D 24-hydroxylase } \\ \text { CYP27A1 } & \text { sterol 27-hydroxylase } \\ \text { CYP27B1 } & \text { 25-hydroxyvitamin D-1 } \alpha \text {-hydroxylase } \\ \text { CYP2R1 } & \text { vitamin D-25-hydroxylase } \\ \text { CYP7A1 } & \text { cholesterol 7 } \alpha \text {-hydroxylase } \\ \text { DBP } & \text { vitamin-D-binding protein GC } \\ \text { DHCR7 } & \text { 7-dehydrocholesterol reductase } \\ \text { DKK1 } & \text { dickkopf 1 } \\ \text { DKK2 } & \text { dickkopf 2 } \\ \text { DPD } & \text { desoxypyridinolin }\end{array}$


ECM extracellular matrix

ELISA enzyme-linked immunosorbent assay

EIA (solid-phase) enzyme immunoassay

FGF fibroblast growth factors

$\mathrm{GH}$ growth hormone

HBV hepatitis B virus

$\mathrm{HCV}$ hepatitis $\mathrm{C}$ virus

HDAC histone deacetylase

HOD hepatic osteodystrophy

HYP hydroxyprolin

ICTP type I collagen cross-linked C-telopeptide

IGF-1 insulin-like growth factor 1

M-CSF macrophage colony-stimulating factor

MMP matrix metalloproteinase

MSC mesenchymal stem/stromal cell

NAFLD non-alcoholic fatty liver disease

$\mathrm{NASH} \quad$ non-alcoholic steatohepatitis

NTX N-telopeptide crosslinks of type I collagen

OC osteocalcin

OLT orthotopic liver transplantation

OP osteopontin

OPG osteoprotegerin

PBC primary biliary cirrhosis

PDGF platelet-derived growth factor

$\mathrm{Pi} \quad$ inorganic phosphate

PICP type I collagen C-terminal propeptide

PINP type I collagen N-terminal propeptide

PPAR $\gamma$ peroxisome proliferator-activated receptor $\gamma$

PSC primary sclerosing cholangitis

PTH parathyroid hormone

PYD pyridinolin

RANKL receptor activator of nuclear factor kappa B ligand

RIA radioimmunoassay

SARA Smad anchor for receptor activation

Ski v-ski sarcoma viral oncogene homolog

SnoN Ski-like oncogene

TGF- $\beta$ transforming growth forming factor- $\beta$

TRAP5b tartrate-resistant acid phosphatase isoform $5 \mathrm{~b}$

UVB ultraviolet B

VDR vitamin D receptor

VRDE vitamin D response element

VitD vitamin D

$\mathrm{VitD}_{2} \quad$ vitamin $\mathrm{D}_{2}$, also called ergocalciferol

$\mathrm{VitD}_{3} \quad$ vitamin $\mathrm{D}_{3}$, also called cholecalciferol

VitK vitamin K 


\section{Appendix A}

The following search terms were used in PubMed and Web of Science (title and abstract):

\begin{tabular}{ll} 
"hepatic osteodystrophy" & $145 \mathrm{hits}$ \\
"liver disease" and "bone metabolism" & $80 \mathrm{hits}$ \\
"liver disease" and "osteopenia" & $137 \mathrm{hits}$ \\
"liver disease" and "osteoporosis" & $447 \mathrm{hits}$ \\
"liver disease" and "fractures" & $225 \mathrm{hits}$ \\
"hepatitis" and "bone metabolism" & $39 \mathrm{hits}$ \\
"hepatitis" and "osteopenia" & $354 \mathrm{hits}$ \\
"hepatitis" and "osteoporosis" & $340 \mathrm{hits}$ \\
"hepatitis" and "fractures" & $193 \mathrm{hits}$ \\
"liver fibrosis" or "liver cirrhosis" and "bone metabolism" & $48 \mathrm{hits}$ \\
"liver fibrosis" or "liver cirrhosis" and "osteopenia" & $460 \mathrm{hits}$ \\
"liver fibrosis" or "liver cirrhosis" and "osteoporosis" & $375 \mathrm{hits}$ \\
\hline
\end{tabular}

After removal of the duplicates, the manuscripts were screened (abstracts). Only manuscripts available in German and English were considered for further evaluation. Table 1 comprises studies describing human data on patients with defined liver diseases (mixed etiologies are not included).

\section{References}

1. Angulo, P.; Grandison, G.A.; Fong, D.G.; Keach, J.C.; Lindor, K.D.; Bjornsson, E.; Koch, A. Bone disease in patients with primary sclerosing cholangitis. Gastroenterology 2011, 140, 180-188. [CrossRef]

2. Guanabens, N.; Cerda, D.; Monegal, A.; Pons, F.; Caballeria, L.; Peris, P.; Pares, A. Low bone mass and severity of cholestasis affect fracture risk in patients with primary biliary cirrhosis. Gastroenterology 2010, 138, $2348-2356$. [CrossRef] [PubMed]

3. Nakchbandi, I.A.; van der Merwe, S.W. Current understanding of osteoporosis associated with liver disease. Nat. Rev. Gastroenterol. Hepatol. 2009, 6, 660-670. [CrossRef]

4. Diamond, T.; Stiel, D.; Lunzer, M.; Wilkinson, M.; Roche, J.; Posen, S. Osteoporosis and skeletal fractures in chronic liver disease. Gut 1990, 31, 82-87. [CrossRef] [PubMed]

5. Wibaux, C.; Legroux-Gerot, I.; Dharancy, S.; Boleslawski, E.; Declerck, N.; Canva, V.; Mathurin, P.; Pruvot, F.R.; Cortet, B. Assessing bone status in patients awaiting liver transplantation. Jt. Bone Spine 2010, 78, 387-391. [CrossRef] [PubMed]

6. Tsai, C.F.; Liu, C.J.; Chen, T.J.; Chu, C.J.; Lin, H.C.; Lee, F.Y.; Su, T.P.; Lu, C.L. Increased incidence of orthopedic fractures in cirrhotic patients: A nationwide population-based study. J. Hepatol. 2013, 58, 706-714. [CrossRef] [PubMed]

7. Lopez-Larramona, G.; Lucendo, A.J.; Gonzalez-Castillo, S.; Tenias, J.M. Hepatic osteodystrophy: An important matter for consideration in chronic liver disease. World J. Hepatol. 2011, 3, 300-307. [CrossRef] [PubMed]

8. Guarino, M.; Loperto, I.; Camera, S.; Cossiga, V.; Di Somma, C.; Colao, A.; Caporaso, N.; Morisco, F. Osteoporosis across chronic liver disease. Osteoporos. Int. 2016, 27, 1967-1977. [CrossRef]

9. Goel, V.; Kar, P. Hepatic osteodystrophy. Trop. Gastroenterol. 2010, 31, 82-86.

10. Orsini, L.G.; Pinheiro, M.M.; Castro, C.H.; Silva, A.E.; Szejnfeld, V.L. Bone mineral density measurements, bone markers and serum vitamin d concentrations in men with chronic non-cirrhotic untreated hepatitis $\mathrm{c}$. PLoS ONE 2013, 8, e81652. [CrossRef]

11. El-Husseini, A.; Sabry, A.; Hassan, R.; Sobh, M. Effect of chronic hepatitis c virus infection on bone mineral density in pediatric renal transplant recipients. Saudi J. Kidney Dis. Transpl. 2013, 24, 917-924. [CrossRef] [PubMed]

12. Choudhary, N.S.; Tomar, M.; Chawla, Y.K.; Bhadada, S.K.; Khandelwal, N.; Dhiman, R.K.; Duseja, A.; Bhansali, A. Hepatic osteodystrophy is common in patients with noncholestatic liver disease. Dig. Dis. Sci. 2011, 56, 3323-3327. [CrossRef]

13. Keller, S.; Ittrich, H.; Schramm, C.; Lohse, A.W.; Amling, M.; Adam, G.; Yamamura, J. Diffusion-weighted mri for detection of hepatic osteodystrophy in primary sclerosing cholangitis: A comparison study with dual-energy X-ray absorptiometry. Jpn. J. Radiol. 2016, 34, 677-683. [CrossRef]

14. Menon, K.V.; Angulo, P.; Weston, S.; Dickson, E.R.; Lindor, K.D. Bone disease in primary biliary cirrhosis: Independent indicators and rate of progression. J. Hepatol. 2001, 35, 316-323. [CrossRef] 
15. Mounach, A.; Ouzzif, Z.; Wariaghli, G.; Achemlal, L.; Benbaghdadi, I.; Aouragh, A.; Bezza, A.; El Maghraoui, A. Primary biliary cirrhosis and osteoporosis: A case-control study. J. Bone Min. Metab. 2008, 26, 379-384. [CrossRef]

16. Lindor, K.D.; Janes, C.H.; Crippin, J.S.; Jorgensen, R.A.; Dickson, E.R. Bone disease in primary biliary cirrhosis: Does ursodeoxycholic acid make a difference? Hepatology 1995, 21, 389-392. [PubMed]

17. Guanabens, N.; Pares, A.; Marinoso, L.; Brancos, M.A.; Piera, C.; Serrano, S.; Rivera, F.; Rodes, J. Factors influencing the development of metabolic bone disease in primary biliary cirrhosis. Am. J. Gastroenterol. 1990, 85, 1356-1362. [PubMed]

18. Danford, C.J.; Trivedi, H.D.; Papamichael, K.; Tapper, E.B.; Bonder, A. Osteoporosis in primary biliary cholangitis. World J. Gastroenterol. 2018, 24, 3513-3520. [CrossRef] [PubMed]

19. Savic, Z.; Damjanov, D.; Curic, N.; Kovacev-Zavisic, B.; Hadnadjev, L.; Novakovic-Paro, J.; Nikolic, S. Vitamin d status, bone metabolism and bone mass in patients with alcoholic liver cirrhosis. Bratisl. Lek. Listy 2014, 115, 573-578. [CrossRef]

20. Malik, P.; Gasser, R.W.; Kemmler, G.; Moncayo, R.; Finkenstedt, G.; Kurz, M.; Fleischhacker, W.W. Low bone mineral density and impaired bone metabolism in young alcoholic patients without liver cirrhosis: A cross-sectional study. Alcohol. Clin. Exp. Res. 2009, 33, 375-381. [CrossRef]

21. Diamond, T.; Stiel, D.; Lunzer, M.; Wilkinson, M.; Posen, S. Ethanol reduces bone formation and may cause osteoporosis. Am. J. Med. 1989, 86, 282-288. [CrossRef]

22. Pardee, P.E.; Dunn, W.; Schwimmer, J.B. Non-alcoholic fatty liver disease is associated with low bone mineral density in obese children. Aliment. Pharm. Ther. 2012, 35, 248-254. [CrossRef] [PubMed]

23. Kim, G.; Kim, K.J.; Rhee, Y.; Lim, S.K. Significant liver fibrosis assessed using liver transient elastography is independently associated with low bone mineral density in patients with non-alcoholic fatty liver disease. PLoS ONE 2017, 12, e0182202. [CrossRef] [PubMed]

24. Chen, D.Z.; Xu, Q.M.; Wu, X.X.; Cai, C.; Zhang, L.J.; Shi, K.Q.; Shi, H.Y.; Li, L.J. The combined effect of nonalcoholic fatty liver disease and metabolic syndrome on osteoporosis in postmenopausal females in eastern china. Int. J. Endocrinol. 2018, 2018, 2314769. [CrossRef] [PubMed]

25. Diamond, T.; Stiel, D.; Posen, S. Osteoporosis in hemochromatosis: Iron excess, gonadal deficiency, or other factors? Ann. Intern. Med. 1989, 110, 430-436. [CrossRef] [PubMed]

26. Sinigaglia, L.; Fargion, S.; Fracanzani, A.L.; Binelli, L.; Battafarano, N.; Varenna, M.; Piperno, A.; Fiorelli, G. Bone and joint involvement in genetic hemochromatosis: Role of cirrhosis and iron overload. J. Rheumatol. 1997, 24, 1809-1813.

27. Guggenbuhl, P.; Deugnier, Y.; Boisdet, J.F.; Rolland, Y.; Perdriger, A.; Pawlotsky, Y.; Chales, G. Bone mineral density in men with genetic hemochromatosis and hfe gene mutation. Osteoporos. Int. 2005, 16, 1809-1814. [CrossRef] [PubMed]

28. Weiss, K.H.; Van de Moortele, M.; Gotthardt, D.N.; Pfeiffenberger, J.; Seessle, J.; Ullrich, E.; Gielen, E.; Borghs, H.; Adriaens, E.; Stremmel, W.; et al. Bone demineralisation in a large cohort of wilson disease patients. J. Inherit. Metab. Dis. 2015, 38, 949-956. [CrossRef] [PubMed]

29. Quemeneur, A.S.; Trocello, J.M.; Ea, H.K.; Ostertag, A.; Leyendecker, A.; Duclos-Vallee, J.C.; de Vernejoul, M.C.; Woimant, F.; Liote, F. Bone status and fractures in 85 adults with wilson's disease. Osteoporos. Int. 2014, 25, 2573-2580. [CrossRef] [PubMed]

30. Selimoglu, M.A.; Ertekin, V.; Doneray, H.; Yildirim, M. Bone mineral density of children with wilson disease: Efficacy of penicillamine and zinc therapy. J. Clin. Gastroenterol. 2008, 42, 194-198. [CrossRef]

31. Hegedus, D.; Ferencz, V.; Lakatos, P.L.; Meszaros, S.; Lakatos, P.; Horvath, C.; Szalay, F. Decreased bone density, elevated serum osteoprotegerin, and beta-cross-laps in wilson disease. J. Bone Min. Res. 2002, 17, 1961-1967. [CrossRef]

32. Angulo, P.; Therneau, T.M.; Jorgensen, A.; DeSotel, C.K.; Egan, K.S.; Dickson, E.R.; Hay, J.E.; Lindor, K.D. Bone disease in patients with primary sclerosing cholangitis: Prevalence, severity and prediction of progression. J. Hepatol. 1998, 29, 729-735. [CrossRef]

33. Duarte, M.P.; Farias, M.L.; Coelho, H.S.; Mendonca, L.M.; Stabnov, L.M.; do Carmo d Oliveira, M.; Lamy, R.A.; Oliveira, D.S. Calcium-parathyroid hormone-vitamin $\mathrm{d}$ axis and metabolic bone disease in chronic viral liver disease. J. Gastroenterol. Hepatol. 2001, 16, 1022-1027. [CrossRef]

34. Auletta, M.; Nuzzo, V.; Esposito, A.; Antonello, S.; Lupoli, G.; Federico, F.; De Puente, A. Osteoporosis in men: A study in patients affected by chronic non-advanced liver disease. Clin. Cases Min. Bone Metab. $2005,2,25-28$. 
35. Hofmann, W.P.; Kronenberger, B.; Bojunga, J.; Stamm, B.; Herrmann, E.; Bucker, A.; Mihm, U.; von Wagner, M.; Zeuzem, S.; Sarrazin, C. Prospective study of bone mineral density and metabolism in patients with chronic hepatitis c during pegylated interferon alpha and ribavirin therapy. J. Viral. Hepat. 2008, 15, 790-796.

36. Lin, J.C.; Hsieh, T.Y.; Wu, C.C.; Chen, P.J.; Chueh, T.H.; Chang, W.K.; Chu, H.C. Association between chronic hepatitis c virus infection and bone mineral density. Calcif. Tissue Int. 2012, 91, 423-429. [CrossRef]

37. Lai, J.C.; Shoback, D.M.; Zipperstein, J.; Lizaola, B.; Tseng, S.; Terrault, N.A. Bone mineral density, bone turnover, and systemic inflammation in non-cirrhotics with chronic hepatitis c. Dig. Dis. Sci. 2015, 60, 1813-1819. [CrossRef]

38. Huang, Z.; Wei, H.; Cheng, C.; Yang, S.; Wang, J.; Liu, X. Low bone mineral density in chronic hepatitis b virus infection: A case-control study. Pak. J. Med. Sci. 2017, 33, 457-461. [CrossRef]

39. Bering, T.; Diniz, K.G.D.; Coelho, M.P.P.; Vieira, D.A.; Soares, M.M.S.; Kakehasi, A.M.; Correia, M.; Teixeira, R.; Queiroz, D.M.M.; Rocha, G.A.; et al. Association between pre-sarcopenia, sarcopenia, and bone mineral density in patients with chronic hepatitis c. J. Cachexia Sarcopenia Muscle 2018, 9, 255-268. [CrossRef]

40. Gallego-Rojo, F.J.; Gonzalez-Calvin, J.L.; Munoz-Torres, M.; Mundi, J.L.; Fernandez-Perez, R.; Rodrigo-Moreno, D. Bone mineral density, serum insulin-like growth factor i, and bone turnover markers in viral cirrhosis. Hepatology 1998, 28, 695-699. [CrossRef]

41. George, J.; Ganesh, H.K.; Acharya, S.; Bandgar, T.R.; Shivane, V.; Karvat, A.; Bhatia, S.J.; Shah, S.; Menon, P.S.; Shah, N. Bone mineral density and disorders of mineral metabolism in chronic liver disease. World J. Gastroenterol. 2009, 15, 3516-3522. [CrossRef]

42. Goubraim, R.; Kabbaj, N.; Salihoun, M.; Chaoui, Z.; Nya, M.; Amrani, N. Metabolic bone disease in viral cirrhosis: A prospective study. ISRN Hepatol. 2013, 2013, 276563. [CrossRef] [PubMed]

43. Karoli, Y.; Karoli, R.; Fatima, J.; Manhar, M. Study of hepatic osteodystrophy in patients with chronic liver disease. J. Clin. Diagn. Res. 2016, 10, OC31-OC34. [CrossRef]

44. Spencer, H.; Rubio, N.; Rubio, E.; Indreika, M.; Seitam, A. Chronic alcoholism. Frequently overlooked cause of osteoporosis in men. Am. J. Med. 1986, 80, 393-397. [CrossRef]

45. Gonzalez-Calvin, J.L.; Garcia-Sanchez, A.; Bellot, V.; Munoz-Torres, M.; Raya-Alvarez, E.; Salvatierra-Rios, D. Mineral metabolism, osteoblastic function and bone mass in chronic alcoholism. Alcohol Alcohol. 1993, 28, 571-579.

46. Kim, S.; Koga, T.; Isobe, M.; Kern, B.E.; Yokochi, T.; Chin, Y.E.; Karsenty, G.; Taniguchi, T.; Takayanagi, H. Stat1 functions as a cytoplasmic attenuator of runx2 in the transcriptional program of osteoblast differentiation. Genes Dev. 2003, 17, 1979-1991. [CrossRef] [PubMed]

47. Neyeloff, J.L.; Fuchs, S.C.; Moreira, L.B. Meta-analyses and forest plots using a microsoft excel spreadsheet: Step-by-step guide focusing on descriptive data analysis. BMC Res. Notes 2012, 5, 52. [CrossRef] [PubMed]

48. Cunningham, J. Posttransplantation bone disease. Transplantation 2005, 79, 629-634. [CrossRef] [PubMed]

49. Hamburg, S.M.; Piers, D.A.; van den Berg, A.P.; Slooff, M.J.; Haagsma, E.B. Bone mineral density in the long term after liver transplantation. Osteoporos. Int. 2000, 11, 600-606. [CrossRef]

50. Loria, I.; Albanese, C.; Giusto, M.; Galtieri, P.A.; Giannelli, V.; Lucidi, C.; Di Menna, S.; Pirazzi, C.; Corradini, S.G.; Mennini, G.; et al. Bone disorders in patients with chronic liver disease awaiting liver transplantation. Transpl. Proc. 2010, 42, 1191-1193. [CrossRef]

51. Guichelaar, M.M.; Kendall, R.; Malinchoc, M.; Hay, J.E. Bone mineral density before and after olt: Long-term follow-up and predictive factors. Liver Transpl. 2006, 12, 1390-1402. [CrossRef] [PubMed]

52. Hay, J.E. Osteoporosis in liver diseases and after liver transplantation. J. Hepatol. 2003, 38, 856-865. [CrossRef]

53. Ulivieri, F.M.; Silva, B.C.; Sardanelli, F.; Hans, D.; Bilezikian, J.P.; Caudarella, R. Utility of the trabecular bone score (tbs) in secondary osteoporosis. Endocrine 2014, 47, 435-448. [CrossRef]

54. Sheu, A.; Diamond, T. Bone mineral density: Testing for osteoporosis. Aust. Prescr. 2016, 39, 35-39. [CrossRef]

55. Coates, P. Bone turnover markers. Aust. Fam. Physician 2013, 42, 285-287.

56. Nishizawa, Y.; Ohta, H.; Miura, M.; Inaba, M.; Ichimura, S.; Shiraki, M.; Takada, J.; Chaki, O.; Hagino, H.; Fujiwara, S.; et al. Guidelines for the use of bone metabolic markers in the diagnosis and treatment of osteoporosis (2012 edition). J. Bone Min. Metab. 2013, 31, 1-15. [CrossRef]

57. Szulc, P. The role of bone turnover markers in monitoring treatment in postmenopausal osteoporosis. Clin. Biochem. 2012, 45, 907-919. [CrossRef]

58. Szulc, P.; Delmas, P.D. Biochemical markers of bone turnover: Potential use in the investigation and management of postmenopausal osteoporosis. Osteoporos. Int. 2008, 19, 1683-1704. [CrossRef]

59. Liu, T.; Wang, X.; Karsdal, M.A.; Leeming, D.J.; Genovese, F. Molecular serum markers of liver fibrosis. Biomark. Insights 2012, 7, 105-117. [CrossRef] [PubMed] 
60. Duarte, S.; Baber, J.; Fujii, T.; Coito, A.J. Matrix metalloproteinases in liver injury, repair and fibrosis. Matrix Biol. 2015, 44-46, 147-156. [CrossRef]

61. Naim, A.; Pan, Q.; Baig, M.S. Matrix metalloproteinases (mmps) in liver diseases. J. Clin. Exp. Hepatol. 2017, 7, 367-372. [CrossRef] [PubMed]

62. Hajiabbasi, A.; Shafaghi, A.; Fayazi, H.S.; Shenavar Masooleh, I.; Hedayati Emami, M.H.; Ghavidel Parsa, P.; Amir Maafi, A. The factors affecting bone density in cirrhosis. Hepat. Mon. 2015, 15, e26871. [CrossRef]

63. Asomaning, K.; Bertone-Johnson, E.R.; Nasca, P.C.; Hooven, F.; Pekow, P.S. The association between body mass index and osteoporosis in patients referred for a bone mineral density examination. J. Womens Health 2006, 15, 1028-1034. [CrossRef]

64. Collier, J. Bone disorders in chronic liver disease. Hepatology 2007, 46, 1271-1278. [CrossRef]

65. Hay, J.E.; Guichelaar, M.M. Evaluation and management of osteoporosis in liver disease. Clin. Liver Dis. 2005, 9, 747-766. [CrossRef]

66. Guanabens, N.; Pares, A.; Ros, I.; Caballeria, L.; Pons, F.; Vidal, S.; Monegal, A.; Peris, P.; Rodes, J. Severity of cholestasis and advanced histological stage but not menopausal status are the major risk factors for osteoporosis in primary biliary cirrhosis. J. Hepatol. 2005, 42, 573-577. [CrossRef]

67. Gonzalez-Reimers, E.; Alvisa-Negrin, J.; Santolaria-Fernandez, F.; Candelaria Martin-Gonzalez, M.; Hernandez-Betancor, I.; Fernandez-Rodriguez, C.M.; Vina-Rodriguez, J.; Gonzalez-Diaz, A. Vitamin d and nutritional status are related to bone fractures in alcoholics. Alcohol Alcohol. 2011, 46, 148-155. [CrossRef]

68. Santori, C.; Ceccanti, M.; Diacinti, D.; Attilia, M.L.; Toppo, L.; D’Erasmo, E.; Romagnoli, E.; Mascia, M.L.; Cipriani, C.; Prastaro, A.; et al. Skeletal turnover, bone mineral density, and fractures in male chronic abusers of alcohol. J. Endocrinol. Investig. 2008, 31, 321-326. [CrossRef]

69. Sampson, H.W. Alcohol, osteoporosis, and bone regulating hormones. Alcohol. Clin. Exp. Res. 1997, 21, 400-403. [CrossRef]

70. Laitinen, K.; Valimaki, M. Alcohol and bone. Calcif. Tissue Int. 1991, 49 (Suppl. 1), S70-S73. [CrossRef]

71. Maran, A.; Zhang, M.; Spelsberg, T.C.; Turner, R.T. The dose-response effects of ethanol on the human fetal osteoblastic cell line. J. Bone Min. Res. 2001, 16, 270-276. [CrossRef] [PubMed]

72. Karlsson, K.M.; Karlsson, C.; Ahlborg, H.G.; Valdimarsson, O.; Ljunghall, S.; Obrant, K.J. Bone turnover responses to changed physical activity. Calcif. Tissue Int. 2003, 72, 675-680. [CrossRef] [PubMed]

73. Bailey, D.A.; McCulloch, R.G. Bone tissue and physical activity. Can. J. Sport Sci. 1990, 15, 229-239. [PubMed]

74. Scharf, J.G.; Schmitz, F.; Frystyk, J.; Skjaerbaek, C.; Moesus, H.; Blum, W.F.; Ramadori, G.; Hartmann, H. Insulin-like growth factor-i serum concentrations and patterns of insulin-like growth factor binding proteins in patients with chronic liver disease. J. Hepatol. 1996, 25, 689-699. [CrossRef]

75. Foresta, C.; Schipilliti, M.; Ciarleglio, F.A.; Lenzi, A.; D'Amico, D. Male hypogonadism in cirrhosis and after liver transplantation. J. Endocrinol. Investig. 2008, 31, 470-478. [CrossRef] [PubMed]

76. Veldurthy, V.; Wei, R.; Oz, L.; Dhawan, P.; Jeon, Y.H.; Christakos, S. Vitamin d, calcium homeostasis and aging. Bone Res. 2016, 4, 16041. [CrossRef]

77. Christakos, S.; Dhawan, P.; Porta, A.; Mady, L.J.; Seth, T. Vitamin d and intestinal calcium absorption. Mol. Cell. Endocrinol. 2011, 347, 25-29. [CrossRef] [PubMed]

78. Jamil, Z.; Arif, S.; Khan, A.; Durrani, A.A.; Yaqoob, N. Vitamin d deficiency and its relationship with child-pugh class in patients with chronic liver disease. J. Clin. Transl. Hepatol. 2018, 6, 135-140. [CrossRef] [PubMed]

79. Zhao, X.Y.; Li, J.; Wang, J.H.; Habib, S.; Wei, W.; Sun, S.J.; Strobel, H.W.; Jia, J.D. Vitamin d serum level is associated with child-pugh score and metabolic enzyme imbalances, but not viral load in chronic hepatitis $b$ patients. Medicine 2016, 95, e3926. [CrossRef]

80. Corey, R.L.; Whitaker, M.D.; Crowell, M.D.; Keddis, M.T.; Aqel, B.; Balan, V.; Byrne, T.; Carey, E.; Douglas, D.D.; Harrison, M.E.; et al. Vitamin d deficiency, parathyroid hormone (pth) levels, and bone disease among patients with end stage liver disease (esld) and normal serum creatinine awaiting liver transplantation (lt). Clin. Transpl. 2014, 28, 579-584. [CrossRef]

81. Garingarao, C.J.; Paz-Pacheco, E.; Jimeno, C.A. Primary hyperparathyroidism from a probable ectopic parathyroid adenoma with severe skeletal disease and vitamin d deficiency. BMJ Case Rep. 2014, 2014, bcr2014203716. [CrossRef]

82. Nishiguchi, S.; Shimoi, S.; Kurooka, H.; Tamori, A.; Habu, D.; Takeda, T.; Kubo, S. Randomized pilot trial of vitamin $\mathrm{k} 2$ for bone loss in patients with primary biliary cirrhosis. J. Hepatol. 2001, 35, 543-545. [CrossRef] 
83. Levy, C.; Lindor, K.D. Management of osteoporosis, fat-soluble vitamin deficiencies, and hyperlipidemia in primary biliary cirrhosis. Clin. Liver Dis. 2003, 7, 901-910. [CrossRef]

84. Plaza, S.M.; Lamson, D.W. Vitamin k2 in bone metabolism and osteoporosis. Altern. Med. Rev. 2005, 10, $24-35$.

85. Liu, Z.; Han, T.; Werner, H.; Rosen, C.J.; Schaffler, M.B.; Yakar, S. Reduced serum igf-1 associated with hepatic osteodystrophy is a main determinant of low cortical but not trabecular bone mass. J. Bone Min. Res. 2018, 33, 123-136. [CrossRef]

86. Bachagol, D.; Joseph, G.S.; Ellur, G.; Patel, K.; Aruna, P.; Mittal, M.; China, S.P.; Singh, R.P.; Sharan, K. Stimulation of liver igf-1 expression promotes peak bone mass achievement in growing rats: A study with pomegranate seed oil. J. Nutr. Biochem. 2018, 52, 18-26. [CrossRef] [PubMed]

87. Marek, B.; Kajdaniuk, D.; Niedziolka, D.; Borgiel-Marek, H.; Nowak, M.; Sieminska, L.; Ostrowska, Z.; Glogowska-Szelag, J.; Piecha, T.; Otremba, L.; et al. Growth hormone/insulin-like growth factor-1 axis, calciotropic hormones and bone mineral density in young patients with chronic viral hepatitis. Endokrynol. Pol. 2015, 66, 22-29. [CrossRef] [PubMed]

88. Dooley, S.; ten Dijke, P. Tgf-beta in progression of liver disease. Cell Tissue Res. 2012, 347, 245-256. [CrossRef] [PubMed]

89. Gressner, A.M.; Weiskirchen, R.; Breitkopf, K.; Dooley, S. Roles of tgf-beta in hepatic fibrosis. Front. Biosci. 2002, 7, d793-d807. [CrossRef]

90. Breitkopf-Heinlein, K.; Meyer, C.; Konig, C.; Gaitantzi, H.; Addante, A.; Thomas, M.; Wiercinska, E.; Cai, C.; Li, Q.; Wan, F.; et al. Bmp-9 interferes with liver regeneration and promotes liver fibrosis. Gut 2017, 66, 939-954. [CrossRef] [PubMed]

91. Weiskirchen, R.; Meurer, S.K.; Gressner, O.A.; Herrmann, J.; Borkham-Kamphorst, E.; Gressner, A.M. Bmp-7 as antagonist of organ fibrosis. Front. Biosci. 2009, 14, 4992-5012. [CrossRef]

92. Diamond, T.; Pojer, R.; Stiel, D.; Alfrey, A.; Posen, S. Does iron affect osteoblast function? Studies in vitro and in patients with chronic liver disease. Calcif. Tissue Int. 1991, 48, 373-379. [CrossRef]

93. Valenti, L.; Varenna, M.; Fracanzani, A.L.; Rossi, V.; Fargion, S.; Sinigaglia, L. Association between iron overload and osteoporosis in patients with hereditary hemochromatosis. Osteoporos. Int. 2009, 20, 549-555. [CrossRef]

94. Janes, C.H.; Dickson, E.R.; Okazaki, R.; Bonde, S.; McDonagh, A.F.; Riggs, B.L. Role of hyperbilirubinemia in the impairment of osteoblast proliferation associated with cholestatic jaundice. J. Clin. Investig. 1995, 95, 2581-2586. [CrossRef] [PubMed]

95. Smith, D.L.; Shire, N.J.; Watts, N.B.; Schmitter, T.; Szabo, G.; Zucker, S.D. Hyperbilirubinemia is not a major contributing factor to altered bone mineral density in patients with chronic liver disease. J. Clin. Densitom. 2006, 9, 105-113. [CrossRef]

96. Weinreb, M.; Pollak, R.D.; Ackerman, Z. Experimental cholestatic liver disease through bile-duct ligation in rats results in skeletal fragility and impaired osteoblastogenesis. J. Hepatol. 2004, 40, 385-390. [CrossRef]

97. Christensen, M.H.; Apalset, E.M.; Nordbo, Y.; Varhaug, J.E.; Mellgren, G.; Lien, E.A. 1,25-dihydroxyvitamin $\mathrm{d}$ and the vitamin $\mathrm{d}$ receptor gene polymorphism apa1 influence bone mineral density in primary hyperparathyroidism. PLOS ONE 2013, 8, e56019. [CrossRef]

98. Hay, J.E. Vitamin d receptor polymorphism and posttransplantation bone loss. Liver Transpl. 2001, 7, 68-69. [CrossRef] [PubMed]

99. Pares, A.; Guanabens, N.; Alvarez, L.; De Osaba, M.J.; Oriola, J.; Pons, F.; Caballeria, L.; Monegal, A.; Salvador, G.; Jo, J.; et al. Collagen type ialpha1 and vitamin $\mathrm{d}$ receptor gene polymorphisms and bone mass in primary biliary cirrhosis. Hepatology 2001, 33, 554-560. [CrossRef] [PubMed]

100. Pares, A.; Guanabens, N.; Rodes, J. Gene polymorphisms as predictors of decreased bone mineral density and osteoporosis in primary biliary cirrhosis. Eur. J. Gastroenterol. Hepatol. 2005, 17, 311-315. [CrossRef] [PubMed]

101. Springer, J.E.; Cole, D.E.; Rubin, L.A.; Cauch-Dudek, K.; Harewood, L.; Evrovski, J.; Peltekova, V.D.; Heathcote, E.J. Vitamin d-receptor genotypes as independent genetic predictors of decreased bone mineral density in primary biliary cirrhosis. Gastroenterology 2000, 118, 145-151. [CrossRef]

102. Krishnamoorthy, T.L.; Miezynska-Kurtycz, J.; Hodson, J.; Gunson, B.K.; Neuberger, J.; Milkiewicz, P.; Oo, Y.H. Longterm corticosteroid use after liver transplantation for autoimmune hepatitis is safe and associated with a lower incidence of recurrent disease. Liver Transpl. 2016, 22, 34-41. [CrossRef] 
103. Bozkaya, G.; Nart, A.; Uslu, A.; Onman, T.; Aykas, A.; Dogan, M.; Karaca, B. Impact of calcineurin inhibitors on bone metabolism in primary kidney transplant patients. Transpl. Proc. 2008, 40, 151-155. [CrossRef]

104. Lee, J.; Kim, J.H.; Kim, K.; Jin, H.M.; Lee, K.B.; Chung, D.J.; Kim, N. Ribavirin enhances osteoclast formation through osteoblasts via up-regulation of trance/rankl. Mol. Cell. Biochem. 2007, 296, 17-24. [CrossRef]

105. Narayana, K.; D'Souza, U.J.; Seetharama Rao, K.P. The genotoxic and cytotoxic effects of ribavirin in rat bone marrow. Mutat. Res. 2002, 521, 179-185. [CrossRef]

106. Solis-Herruzo, J.A.; Castellano, G.; Fernandez, I.; Munoz, R.; Hawkins, F. Decreased bone mineral density after therapy with alpha interferon in combination with ribavirin for chronic hepatitis c. J. Hepatol. 2000, 33, 812-817. [CrossRef]

107. Gasser, R.W. Cholestasis and metabolic bone disease-A clinical review. Wien. Med. Wochenschr. 2008, 158, 553-557. [CrossRef]

108. Wintermeyer, E.; Ihle, C.; Ehnert, S.; Stockle, U.; Ochs, G.; de Zwart, P.; Flesch, I.; Bahrs, C.; Nussler, A.K. Crucial role of vitamin $d$ in the musculoskeletal system. Nutrients 2016, 8, 319. [CrossRef]

109. Holick, M.F. Vitamin d: A d-lightful solution for health. J. Investig. Med. 2011, 59, 872-880. [CrossRef]

110. Nussler, A.K.; Wildemann, B.; Freude, T.; Litzka, C.; Soldo, P.; Friess, H.; Hammad, S.; Hengstler, J.G.; Braun, K.F.; Trak-Smayra, V.; et al. Chronic ccl4 intoxication causes liver and bone damage similar to the human pathology of hepatic osteodystrophy: A mouse model to analyse the liver-bone axis. Arch. Toxicol. 2014, 88, 997-1006. [CrossRef]

111. Hochrath, K.; Ehnert, S.; Ackert-Bicknell, C.L.; Lau, Y.; Schmid, A.; Krawczyk, M.; Hengstler, J.G.; Dunn, J.; Hiththetiya, K.; Rathkolb, B.; et al. Modeling hepatic osteodystrophy in abcb4 deficient mice. Bone 2013, 55, 501-511. [CrossRef]

112. Arteh, J.; Narra, S.; Nair, S. Prevalence of vitamin d deficiency in chronic liver disease. Dig. Dis. Sci. 2010, 55, $2624-2628$. [CrossRef] [PubMed]

113. Deluca, H.F. History of the discovery of vitamin $d$ and its active metabolites. BoneKEy Rep. 2014, 3, 479. [CrossRef] [PubMed]

114. Shinchuk, L.; Holick, M.F. Vitamin d and rehabilitation: Improving functional outcomes. Nutr. Clin. Pr. 2007, 22, 297-304. [CrossRef]

115. Booth, D.R.; Ding, N.; Parnell, G.P.; Shahijanian, F.; Coulter, S.; Schibeci, S.D.; Atkins, A.R.; Stewart, G.J.; Evans, R.M.; Downes, M.; et al. Cistromic and genetic evidence that the vitamin d receptor mediates susceptibility to latitude-dependent autoimmune diseases. Genes Immun. 2016, 17, 213-219. [CrossRef] [PubMed]

116. Kang, S.W.; Kim, S.H.; Lee, N.; Lee, W.W.; Hwang, K.A.; Shin, M.S.; Lee, S.H.; Kim, W.U.; Kang, I. 1,25-dihyroxyvitamin $\mathrm{d} 3$ promotes foxp3 expression via binding to vitamin $\mathrm{d}$ response elements in its conserved noncoding sequence region. J. Immunol. 2012, 188, 5276-5282. [CrossRef]

117. Zittermann, A.; Kuhn, J.; Ernst, J.B.; Becker, T.; Larisch, J.; Dreier, J.; Knabbe, C.; Borgermann, J.; Gummert, J.F. Circulating 25-hydroxyvitamin $\mathrm{d}$ and 1,25-dihydroxyvitamin $\mathrm{d}$ concentrations and postoperative infections in cardiac surgical patients: The calcitop-study. PLoS ONE 2016, 11, e0158532. [CrossRef]

118. Shymanskyi, I.; Lisakovska, O.; Mazanova, A.; Labudzynskyi, D.; Veliky, M. Vitamin d3 modulates impaired crosstalk between rank and glucocorticoid receptor signaling in bone marrow cells after chronic prednisolone administration. Front. Endocrinol. 2018, 9, 303. [CrossRef]

119. Wacker, M.; Holick, M.F. Vitamin d-effects on skeletal and extraskeletal health and the need for supplementation. Nutrients 2013, 5, 111-148. [CrossRef]

120. Takahashi, N.; Udagawa, N.; Suda, T. Vitamin d endocrine system and osteoclasts. BoneKEy Rep. $2014,3,495$. [CrossRef]

121. Mercer, K.E.; Wynne, R.A.; Lazarenko, O.P.; Lumpkin, C.K.; Hogue, W.R.; Suva, L.J.; Chen, J.R.; Mason, A.Z.; Badger, T.M.; Ronis, M.J. Vitamin d supplementation protects against bone loss associated with chronic alcohol administration in female mice. J. Pharm. Exp. Ther. 2012, 343, 401-412. [CrossRef] [PubMed]

122. Rode, A.; Fourlanos, S.; Nicoll, A. Oral vitamin d replacement is effective in chronic liver disease. Gastroenterol. Clin. Biol. 2010, 34, 618-620. [CrossRef] [PubMed]

123. Maalouf, N.M.; Sakhaee, K. Treatment of osteoporosis in patients with chronic liver disease and in liver transplant recipients. Curr. Treat. Opt. Gastroenterol. 2006, 9, 456-463. [CrossRef] 
124. Yurci, A.; Kalkan, A.O.; Ozbakir, O.; Karaman, A.; Torun, E.; Kula, M.; Baskol, M.; Gursoy, S.; Yucesoy, M.; Bayram, F. Efficacy of different therapeutic regimens on hepatic osteodystrophy in chronic viral liver disease. Eur. J. Gastroenterol. Hepatol. 2011, 23, 1206-1212. [CrossRef] [PubMed]

125. Quesada-Gomez, J.M.; Bouillon, R. Is calcifediol better than cholecalciferol for vitamin d supplementation? Osteoporos. Int. 2018, 29, 1697-1711. [CrossRef]

126. Cesareo, R.; Attanasio, R.; Caputo, M.; Castello, R.; Chiodini, I.; Falchetti, A.; Guglielmi, R.; Papini, E.; Santonati, A.; Scillitani, A.; et al. Italian association of clinical endocrinologists (ame) and italian chapter of the american association of clinical endocrinologists (aace) position statement: Clinical management of vitamin d deficiency in adults. Nutrients 2018, 10, 546. [CrossRef] [PubMed]

127. Pilz, S.; Zittermann, A.; Trummer, C.; Theiler-Schwetz, V.; Lerchbaum, E.; Keppel, M.H.; Grubler, M.R.; Marz, W.; Pandis, M. Vitamin d testing and treatment: A narrative review of current evidence. Endocr. Connect. 2019, 8, R27-R43. [CrossRef]

128. Guanabens, N.; Pares, A. Management of osteoporosis in liver disease. Clin. Res. Hepatol. Gastroenterol. 2011, 35, 438-445. [CrossRef]

129. Luxon, B.A. Bone disorders in chronic liver diseases. Curr. Gastroenterol. Rep. 2012, 13, 40-48. [CrossRef]

130. Rudic, J.S.; Giljaca, V.; Krstic, M.N.; Bjelakovic, G.; Gluud, C. Bisphosphonates for osteoporosis in primary biliary cirrhosis. Cochrane Database Syst. Rev. 2011, 12, CD009144.

131. Wariaghli, G.; Allali, F.; El Maghraoui, A.; Hajjaj-Hassouni, N. Osteoporosis in patients with primary biliary cirrhosis. Eur. J. Gastroenterol. Hepatol. 2010, 22, 1397-1401. [CrossRef] [PubMed]

132. Danford, C.J.; Trivedi, H.D.; Bonder, A. Bone health in patients with liver diseases. J. Clin. Densitom. 2019, in press. [CrossRef] [PubMed]

133. Sutton, A.L.M.; MacDonald, P.N. Vitamin d: More than a "bone-a-fide" hormone. Mol. Endocrinol. 2003, $17,777-791$. [CrossRef] [PubMed]

134. Lavi-Moshayoff, V.; Wasserman, G.; Meir, T.; Silver, J.; Naveh-Many, T. Pth increases fgf23 gene expression and mediates the high-fgf23 levels of experimental kidney failure: A bone parathyroid feedback loop. Am. J. Physiol. Ren. Physiol 2010, 299, F882-F889. [CrossRef] [PubMed]

135. Silver, J.; Naveh-Many, T. Fgf23 and the parathyroid glands. Pediatr. Nephrol. 2010, 25, 2241-2245. [CrossRef] [PubMed]

136. Ritter, C.S.; Brown, A.J. Direct suppression of pth gene expression by the vitamin $d$ prohormones doxercalciferol and calcidiol requires the vitamin d receptor. J. Mol. Endocrinol. 2011, 46, 63-66. [CrossRef] [PubMed]

137. Bikle, D.D. Vitamin d metabolism, mechanism of action, and clinical applications. Chem. Biol. 2014, 21, 319-329. [CrossRef]

138. Aslan, D.; Andersen, M.D.; Gede, L.B.; de Franca, T.K.; Jorgensen, S.R.; Schwarz, P.; Jorgensen, N.R. Mechanisms for the bone anabolic effect of parathyroid hormone treatment in humans. Scand. J. Clin. Lab. Investig. 2012, 72, 14-22. [CrossRef]

139. Anagnostis, P.; Gkekas, N.K.; Potoupnis, M.; Kenanidis, E.; Tsiridis, E.; Goulis, D.G. New therapeutic targets for osteoporosis. Maturitas 2019, 120,1-6. [CrossRef]

140. Dresner-Pollak, R.; Gabet, Y.; Steimatzky, A.; Hamdani, G.; Bab, I.; Ackerman, Z.; Weinreb, M. Human parathyroid hormone 1-34 prevents bone loss in experimental biliary cirrhosis in rats. Gastroenterology 2008, 134, 259-267. [CrossRef]

141. Prie, D.; Forand, A.; Francoz, C.; Elie, C.; Cohen, I.; Courbebaisse, M.; Eladari, D.; Lebrec, D.; Durand, F.; Friedlander, G. Plasma fibroblast growth factor 23 concentration is increased and predicts mortality in patients on the liver-transplant waiting list. PLoS ONE 2013, 8, e66182. [CrossRef]

142. He, X.; Shen, Y.; Ma, X.; Ying, L.; Peng, J.; Pan, X.; Bao, Y.; Zhou, J. The association of serum fgf23 and non-alcoholic fatty liver disease is independent of vitamin $\mathrm{d}$ in type 2 diabetes patients. Clin. Exp. Pharm. Physiol. 2018, 45, 668-674. [CrossRef] [PubMed]

143. Bihari, C.; Lal, D.; Thakur, M.; Sukriti, S.; Mathur, D.; Patil, A.G.; Anand, L.; Kumar, G.; Sharma, S.; Thapar, S.; et al. Suboptimal level of bone-forming cells in advanced cirrhosis are associated with hepatic osteodystrophy. Hepatol. Commun. 2018, 2, 1095-1110. [CrossRef]

144. Tejwani, V.; Qian, Q. Calcium regulation and bone mineral metabolism in elderly patients with chronic kidney disease. Nutrients 2013, 5, 1913-1936. [CrossRef] [PubMed] 
145. Carrillo-Lopez, N.; Roman-Garcia, P.; Rodriguez-Rebollar, A.; Fernandez-Martin,J.L.; Naves-Diaz, M.; Cannata-Andia, J.B. Indirect regulation of pth by estrogens may require fgf23. J. Am. Soc. Nephrol. 2009, 20, 2009-2017. [CrossRef] [PubMed]

146. Carpinteri, R.; Porcelli, T.; Mejia, C.; Patelli, I.; Bilezikian, J.P.; Canalis, E.; Angeli, A.; Giustina, A.; Mazziotti, G. Glucocorticoid-induced osteoporosis and parathyroid hormone. J. Endocrinol. Investig. 2010, 33, 16-21.

147. Felsenfeld, A.J.; Levine, B.S. Calcitonin, the forgotten hormone: Does it deserve to be forgotten? Clin. Kidney J. 2015, 8, 180-187. [CrossRef]

148. Cochran, M.; Peacock, M.; Sachs, G.; Nordin, B.E. Renal effects of calcitonin. Br. Med. J. 1970, 1, $135-137$. [CrossRef]

149. Mirzaei, S.; Krotla, G.; Knoll, P.; Koriska, K.; Kohn, H. Possible effect of calcitonin deficiency on bone mass after subtotal thyroidectomy. Acta Med. Austriaca 1999, 26, 29-31. [PubMed]

150. Giannini, S.; Nobile, M.; Sartori, L.; Binotto, P.; Ciuffreda, M.; Gemo, G.; Pelizzo, M.R.; D’Angelo, A.; Crepaldi, G. Bone density and mineral metabolism in thyroidectomized patients treated with long-term 1-thyroxine. Clin. Sci. 1994, 87, 593-597. [CrossRef]

151. Gonzalez, D.C.; Mautalen, C.A.; Correa, P.H.; el Tamer, E.; el Tamer, S. Bone mass in totally thyroidectomized patients. Role of calcitonin deficiency and exogenous thyroid treatment. Acta Endocrinol. 1991, 124, 521-525. [CrossRef]

152. Novince, C.M.; Michalski, M.N.; Koh, A.J.; Sinder, B.P.; Entezami, P.; Eber, M.R.; Pettway, G.J.; Rosol, T.J.; Wronski, T.J.; Kozloff, K.M.; et al. Proteoglycan 4: A dynamic regulator of skeletogenesis and parathyroid hormone skeletal anabolism. J. Bone Min. Res. 2013, 27, 11-25. [CrossRef] [PubMed]

153. Carey, R.M.; Siragy, H.M. The intrarenal renin-angiotensin system and diabetic nephropathy. Trends Endocrin. Met. 2003, 14, 274-281. [CrossRef]

154. Williams, S.; Malatesta, K.; Norris, K. Vitamin d and chronic kidney disease. Ethn. Dis. 2009, 19, As8-As11.

155. Putz-Bankuti, C.; Pilz, S.; Stojakovic, T.; Scharnagl, H.; Pieber, T.R.; Trauner, M.; Obermayer-Pietsch, B.; Stauber, R.E. Association of 25-hydroxyvitamin d levels with liver dysfunction and mortality in chronic liver disease. Liver Int. 2012, 32, 845-851. [CrossRef]

156. Li, Y.C. Renoprotective effects of vitamin d analogs. Kidney Int. 2010, 78, 134-139. [CrossRef]

157. Fabregat, I.; Moreno-Caceres, J.; Sanchez, A.; Dooley, S.; Dewidar, B.; Giannelli, G.; Ten Dijke, P.; Consortium, I.-L. Tgf-beta signalling and liver disease. FEBS J. 2016, 283, 2219-2232. [CrossRef]

158. Weng, H.L.; Liu, Y.; Chen, J.L.; Huang, T.; Xu, L.J.; Godoy, P.; Hu, J.H.; Zhou, C.; Stickel, F.; Marx, A.; et al. The etiology of liver damage imparts cytokines transforming growth factor beta1 or interleukin-13 as driving forces in fibrogenesis. Hepatology 2009, 50, 230-243. [CrossRef]

159. Bonewald, L.F.; Dallas, S.L. Role of active and latent transforming growth factor beta in bone formation. J. Cell. Biochem. 1994, 55, 350-357. [CrossRef]

160. Erlebacher, A.; Filvaroff, E.H.; Ye, J.Q.; Derynck, R. Osteoblastic responses to tgf-beta during bone remodeling. Mol. Biol. Cell 1998, 9, 1903-1918. [CrossRef]

161. Robey, P.G.; Young, M.F.; Flanders, K.C.; Roche, N.S.; Kondaiah, P.; Reddi, A.H.; Termine, J.D.; Sporn, M.B.; Roberts, A.B. Osteoblasts synthesize and respond to transforming growth factor-type beta (tgf-beta) in vitro. J. Cell Biol. 1987, 105, 457-463. [CrossRef]

162. Pfeilschifter, J.; Bonewald, L.; Mundy, G.R. Characterization of the latent transforming growth factor beta complex in bone. J. Bone Min. Res. 1990, 5, 49-58. [CrossRef]

163. Oursler, M.J. Osteoclast synthesis and secretion and activation of latent transforming growth factor beta. J. Bone Min. Res. 1994, 9, 443-452. [CrossRef] [PubMed]

164. Dallas, S.L.; Sivakumar, P.; Jones, C.J.; Chen, Q.; Peters, D.M.; Mosher, D.F.; Humphries, M.J.; Kielty, C.M. Fibronectin regulates latent transforming growth factor-beta (tgf beta) by controlling matrix assembly of latent tgf beta-binding protein-1. J. Biol. Chem. 2005, 280, 18871-18880. [CrossRef]

165. Harris, S.E.; Bonewald, L.F.; Harris, M.A.; Sabatini, M.; Dallas, S.; Feng, J.Q.; Ghosh-Choudhury, N.; Wozney, J.; Mundy, G.R. Effects of transforming growth factor beta on bone nodule formation and expression of bone morphogenetic protein 2, osteocalcin, osteopontin, alkaline phosphatase, and type i collagen mrna in long-term cultures of fetal rat calvarial osteoblasts. J. Bone Min. Res. 1994, 9, 855-863. [CrossRef] [PubMed]

166. Ignotz, R.A.; Massague, J. Cell adhesion protein receptors as targets for transforming growth factor-beta action. Cell 1987, 51, 189-197. [CrossRef]

167. Noda, M.; Camilliere, J.J. In vivo stimulation of bone formation by transforming growth factor-beta. Endocrinology 1989, 124, 2991-2994. [CrossRef] 
168. Erlebacher, A.; Derynck, R. Increased expression of tgf-beta 2 in osteoblasts results in an osteoporosis-like phenotype. J. Cell Biol. 1996, 132, 195-210. [CrossRef]

169. Hata, K.; Takahata, Y.; Murakami, T.; Nishimura, R. Transcriptional network controlling endochondral ossification. J. Bone Metab. 2017, 24, 75-82. [CrossRef]

170. Zimmermann, G.; Henle, P.; Kusswetter, M.; Moghaddam, A.; Wentzensen, A.; Richter, W.; Weiss, S. Tgf-beta1 as a marker of delayed fracture healing. Bone 2005, 36, 779-785. [CrossRef]

171. Lind, M. Growth factor stimulation of bone healing. Effects on osteoblasts, osteomies, and implants fixation. Acta Orthop. Scand. Suppl. 1998, 283, 2-37.

172. Lian, N.; Lin, T.; Liu, W.; Wang, W.; Li, L.; Sun, S.; Nyman, J.S.; Yang, X. Transforming growth factor beta suppresses osteoblast differentiation via the vimentin activating transcription factor 4 (atf4) axis. J. Biol. Chem. 2012, 287, 35975-35984. [CrossRef]

173. Lian, N.; Wang, W.; Li, L.; Elefteriou, F.; Yang, X. Vimentin inhibits atf4-mediated osteocalcin transcription and osteoblast differentiation. J. Biol. Chem. 2009, 284, 30518-30525. [CrossRef]

174. Nishiguchi, M.; Yuasa, K.; Saito, K.; Fukumoto, E.; Yamada, A.; Hasegawa, T.; Yoshizaki, K.; Kamasaki, Y.; Nonaka, K.; Fujiwara, T.; et al. Amelogenin is a negative regulator of osteoclastogenesis via downregulation of rankl, m-csf and fibronectin expression in osteoblasts. Arch. Oral Biol. 2007, 52, 237-243. [CrossRef]

175. Ventura, E.; Weller, M.; Macnair, W.; Eschbach, K.; Beisel, C.; Cordazzo, C.; Claassen, M.; Zardi, L.; Burghardt, I. Tgf-beta induces oncofetal fibronectin that, in turn, modulates tgf-beta superfamily signaling in endothelial cells. J. Cell Sci. 2018, 131, jcs209619. [CrossRef]

176. Sens, C.; Altrock, E.; Rau, K.; Klemis, V.; von Au, A.; Pettera, S.; Uebel, S.; Damm, T.; Tiwari, S.; Moser, M.; et al. An o-glycosylation of fibronectin mediates hepatic osteodystrophy through alpha4beta1 integrin. J. Bone Min. Res. 2017, 32, 70-81. [CrossRef]

177. Kawelke, N.; Bentmann, A.; Hackl, N.; Hager, H.D.; Feick, P.; Geursen, A.; Singer, M.V.; Nakchbandi, I.A. Isoform of fibronectin mediates bone loss in patients with primary biliary cirrhosis by suppressing bone formation. J. Bone Min. Res. 2008, 23, 1278-1286. [CrossRef]

178. Ehnert, S.; Zhao, J.; Pscherer, S.; Freude, T.; Dooley, S.; Kolk, A.; Stockle, U.; Nussler, A.K.; Hube, R. Transforming growth factor beta1 inhibits bone morphogenic protein (bmp)-2 and bmp-7 signaling via upregulation of ski-related novel protein $\mathrm{n}$ (snon): Possible mechanism for the failure of bmp therapy? BMC Med. 2012, 10, 101. [CrossRef]

179. Sosa, I.; Cvijanovic, O.; Celic, T.; Cuculic, D.; Crncevic-Orlic, Z.; Vukelic, L.; Zoricic Cvek, S.; Dudaric, L.; Bosnar, A.; Bobinac, D. Hepatoregenerative role of bone morphogenetic protein-9. Med. Sci. Monit. 2011, 17, HY33-HY35. [CrossRef]

180. Derynck, R.; Zhang, Y.E. Smad-dependent and smad-independent pathways in tgf-beta family signalling. Nature 2003, 425, 577-584. [CrossRef]

181. Shi, Y.; Massague, J. Mechanisms of tgf-beta signaling from cell membrane to the nucleus. Cell 2003, 113, 685-700. [CrossRef]

182. Mueller, T.D.; Nickel, J. Promiscuity and specificity in bmp receptor activation. FEBS Lett. 2012, 586, $1846-1859$. [CrossRef] [PubMed]

183. Miyazawa, K.; Shinozaki, M.; Hara, T.; Furuya, T.; Miyazono, K. Two major smad pathways in tgf-beta superfamily signalling. Genes Cells 2002, 7, 1191-1204. [CrossRef] [PubMed]

184. Wu, M.; Chen, G.; Li, Y.P. Tgf-beta and bmp signaling in osteoblast, skeletal development, and bone formation, homeostasis and disease. Bone Res. 2016, 4, 16009. [CrossRef]

185. Zhu, W.; Kim, J.; Cheng, C.; Rawlins, B.A.; Boachie-Adjei, O.; Crystal, R.G.; Hidaka, C. Noggin regulation of bone morphogenetic protein (bmp) 2/7 heterodimer activity in vitro. Bone 2006, 39, 61-71. [CrossRef]

186. Vega, R.B.; Matsuda, K.; Oh, J.; Barbosa, A.C.; Yang, X.; Meadows, E.; McAnally, J.; Pomajzl, C.; Shelton, J.M.; Richardson, J.A.; et al. Histone deacetylase 4 controls chondrocyte hypertrophy during skeletogenesis. Cell 2004, 119, 555-566. [CrossRef] [PubMed]

187. Kang, J.S.; Alliston, T.; Delston, R.; Derynck, R. Repression of runx2 function by tgf-beta through recruitment of class ii histone deacetylases by smad3. EMBO J. 2005, 24, 2543-2555. [CrossRef] [PubMed]

188. Ehnert, S.; Sreekumar, V.; Aspera-Werz, R.H.; Sajadian, S.O.; Wintermeyer, E.; Sandmann, G.H.; Bahrs, C.; Hengstler, J.G.; Godoy, P.; Nussler, A.K. Tgf-beta1 impairs mechanosensation of human osteoblasts via hdac6-mediated shortening and distortion of primary cilia. J. Mol. Med. 2017, 95, 653-663. [CrossRef] 
189. Ehnert, S.; Heuberger, E.; Linnemann, C.; Nussler, A.K.; Pscherer, S. Tgf- $\beta 1$-dependent downregulation of hdac9 inhibits maturation of human osteoblasts. J. Funct. Morphol. Kinesiol. 2017, 2, 41. [CrossRef]

190. Choo, M.K.; Yeo, H.; Zayzafoon, M. Nfatc1 mediates hdac-dependent transcriptional repression of osteocalcin expression during osteoblast differentiation. Bone 2009, 45, 579-589. [CrossRef]

191. Jensen, E.D.; Schroeder, T.M.; Bailey, J.; Gopalakrishnan, R.; Westendorf, J.J. Histone deacetylase 7 associates with runx2 and represses its activity during osteoblast maturation in a deacetylation-independent manner. J. Bone Min. Res. 2008, 23, 361-372. [CrossRef]

192. Vrtacnik, P.; Zupan, J.; Mlakar, V.; Kranjc, T.; Marc, J.; Kern, B.; Ostanek, B. Epigenetic enzymes influenced by oxidative stress and hypoxia mimetic in osteoblasts are differentially expressed in patients with osteoporosis and osteoarthritis. Sci. Rep. 2018, 8, 16215. [CrossRef] [PubMed]

193. Chang, S.; McKinsey, T.A.; Zhang, C.L.; Richardson, J.A.; Hill, J.A.; Olson, E.N. Histone deacetylases 5 and 9 govern responsiveness of the heart to a subset of stress signals and play redundant roles in heart development. Mol. Cell. Biol. 2004, 24, 8467-8476. [CrossRef] [PubMed]

194. Chen, C.; Wei, X.; Wang, S.; Jiao, Q.; Zhang, Y.; Du, G.; Wang, X.; Wei, F.; Zhang, J.; Wei, L. Compression regulates gene expression of chondrocytes through hdac4 nuclear relocation via pp2a-dependent hdac4 dephosphorylation. Biochim. Biophys. Acta 2016, 1863, 1633-1642. [CrossRef]

195. Guan, Y.; Chen, Q.; Yang, X.; Haines, P.; Pei, M.; Terek, R.; Wei, X.; Zhao, T.; Wei, L. Subcellular relocation of histone deacetylase 4 regulates growth plate chondrocyte differentiation through $\mathrm{Ca}^{2+} / \mathrm{calmodulin}^{2}$ dependent kinase iv. Am. J. Physiol. Cell Physiol. 2012, 303, C33-C40. [CrossRef] [PubMed]

196. Nakatani, T.; Chen, T.; Johnson, J.; Westendorf, J.J.; Partridge, N.C. The deletion of hdac4 in mouse osteoblasts influences both catabolic and anabolic effects in bone. J. Bone Min. Res. 2018, 33, 1362-1375. [CrossRef]

197. Feigenson, M.; Shull, L.C.; Taylor, E.L.; Camilleri, E.T.; Riester, S.M.; van Wijnen, A.J.; Bradley, E.W.; Westendorf, J.J. Histone deacetylase 3 deletion in mesenchymal progenitor cells hinders long bone development. J. Bone Min. Res. 2017, 32, 2453-2465. [CrossRef]

198. Razidlo, D.F.; Whitney, T.J.; Casper, M.E.; McGee-Lawrence, M.E.; Stensgard, B.A.; Li, X.; Secreto, F.J.; Knutson, S.K.; Hiebert, S.W.; Westendorf, J.J. Histone deacetylase 3 depletion in osteo/chondroprogenitor cells decreases bone density and increases marrow fat. PLoS ONE 2010, 5, e11492. [CrossRef] [PubMed]

199. Knutson, S.K.; Chyla, B.J.; Amann, J.M.; Bhaskara, S.; Huppert, S.S.; Hiebert, S.W. Liver-specific deletion of histone deacetylase 3 disrupts metabolic transcriptional networks. EMBO J. 2008, 27, 1017-1028. [CrossRef]

200. Montgomery, R.L.; Potthoff, M.J.; Haberland, M.; Qi, X.; Matsuzaki, S.; Humphries, K.M.; Richardson, J.A.; Bassel-Duby, R.; Olson, E.N. Maintenance of cardiac energy metabolism by histone deacetylase 3 in mice. J. Clin. Investig. 2008, 118, 3588-3597. [CrossRef]

201. McGee-Lawrence, M.E.; Carpio, L.R.; Schulze, R.J.; Pierce, J.L.; McNiven, M.A.; Farr, J.N.; Khosla, S.; Oursler, M.J.; Westendorf, J.J. Hdac3 deficiency increases marrow adiposity and induces lipid storage and glucocorticoid metabolism in osteochondroprogenitor cells. J. Bone Min. Res. 2016, 31, 116-128. [CrossRef]

202. Zimmermann, S.; Kiefer, F.; Prudenziati, M.; Spiller, C.; Hansen, J.; Floss, T.; Wurst, W.; Minucci, S.; Gottlicher, M. Reduced body size and decreased intestinal tumor rates in hdac2-mutant mice. Cancer Res. 2007, 67, 9047-9054. [CrossRef]

203. Stemig, M.; Astelford, K.; Emery, A.; Cho, J.J.; Allen, B.; Huang, T.H.; Gopalakrishnan, R.; Mansky, K.C.; Jensen, E.D. Deletion of histone deacetylase 7 in osteoclasts decreases bone mass in mice by interactions with mitf. PLoS ONE 2015, 10, e0123843. [CrossRef]

204. Haberland, M.; Mokalled, M.H.; Montgomery, R.L.; Olson, E.N. Epigenetic control of skull morphogenesis by histone deacetylase 8. Genes Dev. 2009, 23, 1625-1630. [CrossRef] [PubMed]

205. Rivadeneira, F.; Styrkarsdottir, U.; Estrada, K.; Halldorsson, B.V.; Hsu, Y.H.; Richards, J.B.; Zillikens, M.C.; Kavvoura, F.K.; Amin, N.; Aulchenko, Y.S.; et al. Twenty bone-mineral-density loci identified by large-scale meta-analysis of genome-wide association studies. Nat. Genet. 2009, 41, 1199-1206. [PubMed]

206. Westendorf, J.J.; Zaidi, S.K.; Cascino, J.E.; Kahler, R.; van Wijnen, A.J.; Lian, J.B.; Yoshida, M.; Stein, G.S.; $\mathrm{Li}, \mathrm{X}$. Runx2 (cbfa1, aml-3) interacts with histone deacetylase 6 and represses the p21(cip1/waf1) promoter. Mol. Cell. Biol. 2002, 22, 7982-7992. [CrossRef] [PubMed]

207. Wein, M.N.; Spatz, J.; Nishimori, S.; Doench, J.; Root, D.; Babij, P.; Nagano, K.; Baron, R.; Brooks, D.; Bouxsein, M.; et al. Hdac5 controls mef2c-driven sclerostin expression in osteocytes. J. Bone Min. Res. 2015, 30, 400-411. [CrossRef] 
208. Chen, W.; Sheng, P.; Huang, Z.; Meng, F.; Kang, Y.; Huang, G.; Zhang, Z.; Liao, W.; Zhang, Z. Microrna-381 regulates chondrocyte hypertrophy by inhibiting histone deacetylase 4 expression. Int. J. Mol. Sci. 2016, 17, 1377. [CrossRef]

209. Arnold, M.A.; Kim, Y.; Czubryt, M.P.; Phan, D.; McAnally, J.; Qi, X.; Shelton, J.M.; Richardson, J.A.; Bassel-Duby, R.; Olson, E.N. Mef2c transcription factor controls chondrocyte hypertrophy and bone development. Dev. Cell 2007, 12, 377-389. [CrossRef]

210. Jeon, E.J.; Lee, K.Y.; Choi, N.S.; Lee, M.H.; Kim, H.N.; Jin, Y.H.; Ryoo, H.M.; Choi, J.Y.; Yoshida, M.; Nishino, N.; et al. Bone morphogenetic protein-2 stimulates runx2 acetylation. J. Biol. Chem. 2006, 281, 16502-16511. [CrossRef]

211. Schroeder, T.M.; Kahler, R.A.; Li, X.; Westendorf, J.J. Histone deacetylase 3 interacts with runx2 to repress the osteocalcin promoter and regulate osteoblast differentiation. J. Biol. Chem. 2004, 279, 41998-42007. [CrossRef] [PubMed]

212. Lamour, V.; Detry, C.; Sanchez, C.; Henrotin, Y.; Castronovo, V.; Bellahcene, A. Runx2- and histone deacetylase 3-mediated repression is relieved in differentiating human osteoblast cells to allow high bone sialoprotein expression. J. Biol. Chem. 2007, 282, 36240-36249. [CrossRef] [PubMed]

213. Hesse, E.; Saito, H.; Kiviranta, R.; Correa, D.; Yamana, K.; Neff, L.; Toben, D.; Duda, G.; Atfi, A.; Geoffroy, V.; et al. Zfp521 controls bone mass by hdac3-dependent attenuation of runx2 activity. J. Cell Biol. 2010, 191, 1271-1283. [CrossRef]

214. Lee, H.W.; Suh, J.H.; Kim, A.Y.; Lee, Y.S.; Park, S.Y.; Kim, J.B. Histone deacetylase 1-mediated histone modification regulates osteoblast differentiation. Mol. Endocrinol. 2006, 20, 2432-2443. [CrossRef]

215. Fu, Y.; Zhang, P.; Ge, J.; Cheng, J.; Dong, W.; Yuan, H.; Du, Y.; Yang, M.; Sun, R.; Jiang, H. Histone deacetylase 8 suppresses osteogenic differentiation of bone marrow stromal cells by inhibiting histone h3k9 acetylation and runx2 activity. Int. J. Biochem. Cell Biol. 2014, 54, 68-77. [CrossRef] [PubMed]

216. Wheway, G.; Nazlamova, L.; Hancock, J.T. Signaling through the primary cilium. Front. Cell Dev. Biol. 2018, 6, 8. [CrossRef]

217. Pala, R.; Alomari, N.; Nauli, S.M. Primary cilium-dependent signaling mechanisms. Int. J. Mol. Sci. 2017, 18, 2272. [CrossRef] [PubMed]

218. Veland, I.R.; Awan, A.; Pedersen, L.B.; Yoder, B.K.; Christensen, S.T. Primary cilia and signaling pathways in mammalian development, health and disease. Nephron Physiol. 2009, 111, p39-p53. [CrossRef]

219. Schoepflin, Z.R.; Shapiro, I.M.; Risbud, M.V. Class i and iia hdacs mediate hif-1alpha stability through phd2-dependent mechanism, while hdac6, a class iib member, promotes hif-1alpha transcriptional activity in nucleus pulposus cells of the intervertebral disc. J. Bone Min. Res. 2016, 31, 1287-1299. [CrossRef]

220. Rimando, M.G.; Wu, H.H.; Liu, Y.A.; Lee, C.W.; Kuo, S.W.; Lo, Y.P.; Tseng, K.F.; Liu, Y.S.; Lee, O.K. Glucocorticoid receptor and histone deacetylase 6 mediate the differential effect of dexamethasone during osteogenesis of mesenchymal stromal cells (mscs). Sci. Rep. 2016, 6, 37371. [CrossRef]

221. Paino, F.; La Noce, M.; Tirino, V.; Naddeo, P.; Desiderio, V.; Pirozzi, G.; De Rosa, A.; Laino, L.; Altucci, L.; Papaccio, G. Histone deacetylase inhibition with valproic acid downregulates osteocalcin gene expression in human dental pulp stem cells and osteoblasts: Evidence for hdac2 involvement. Stem Cells 2014, 32, 279-289. [CrossRef]

222. La Noce, M.; Mele, L.; Laino, L.; Iolascon, G.; Pieretti, G.; Papaccio, G.; Desiderio, V.; Tirino, V.; Paino, F. Cytoplasmic interactions between the glucocorticoid receptor and hdac2 regulate osteocalcin expression in vpa-treated MSCs. Cells 2019, 8, 217. [CrossRef]

223. Carpio, L.R.; Bradley, E.W.; Westendorf, J.J. Histone deacetylase 3 suppresses erk phosphorylation and matrix metalloproteinase (mmp)-13 activity in chondrocytes. Connect. Tissue Res. 2017, 58, 27-36. [CrossRef] [PubMed]

224. Carpio, L.R.; Bradley, E.W.; McGee-Lawrence, M.E.; Weivoda, M.M.; Poston, D.D.; Dudakovic, A.; Xu, M.; Tchkonia, T.; Kirkland, J.L.; van Wijnen, A.J.; et al. Histone deacetylase 3 supports endochondral bone formation by controlling cytokine signaling and matrix remodeling. Sci. Signal. 2016, 9, ra79. [CrossRef]

225. Nakatani, T.; Chen, T.; Partridge, N.C. Mmp-13 is one of the critical mediators of the effect of hdac4 deletion on the skeleton. Bone 2016, 90, 142-151. [CrossRef] [PubMed]

226. Shimizu, E.; Selvamurugan, N.; Westendorf, J.J.; Olson, E.N.; Partridge, N.C. Hdac4 represses matrix metalloproteinase-13 transcription in osteoblastic cells, and parathyroid hormone controls this repression. J. Biol. Chem. 2010, 285, 9616-9626. [CrossRef] 
227. Shimizu, E.; Selvamurugan, N.; Westendorf, J.J.; Partridge, N.C. Parathyroid hormone regulates histone deacetylases in osteoblasts. Ann. N. Y. Acad. Sci. 2007, 1116, 349-353. [CrossRef] [PubMed]

228. Wang, J.; Wang, C.D.; Zhang, N.; Tong, W.X.; Zhang, Y.F.; Shan, S.Z.; Zhang, X.L.; Li, Q.F. Mechanical stimulation orchestrates the osteogenic differentiation of human bone marrow stromal cells by regulating hdac1. Cell Death Dis. 2016, 7, e2221. [CrossRef] [PubMed]

229. Li, Z.; Hassan, M.Q.; Jafferji, M.; Aqeilan, R.I.; Garzon, R.; Croce, C.M.; van Wijnen, A.J.; Stein, J.L.; Stein, G.S.; Lian, J.B. Biological functions of mir-29b contribute to positive regulation of osteoblast differentiation. J. Biol. Chem. 2009, 284, 15676-15684. [CrossRef] [PubMed]

230. Li, L.; Liu, W.; Wang, H.; Yang, Q.; Zhang, L.; Jin, F.; Jin, Y. Mutual inhibition between hdac9 and mir-17 regulates osteogenesis of human periodontal ligament stem cells in inflammatory conditions. Cell Death Dis. 2018, 9, 480. [CrossRef]

231. Li, C.J.; Cheng, P.; Liang, M.K.; Chen, Y.S.; Lu, Q.; Wang, J.Y.; Xia, Z.Y.; Zhou, H.D.; Cao, X.; Xie, H.; et al. Microrna-188 regulates age-related switch between osteoblast and adipocyte differentiation. J. Clin. Investig. 2015, 125, 1509-1522. [CrossRef]

232. Ota, S.; Zhou, Z.Q.; Romero, M.P.; Yang, G.; Hurlin, P.J. Hdac6 deficiency or inhibition blocks fgfr3 accumulation and improves bone growth in a model of achondroplasia. Hum. Mol. Genet. 2017, $26,3651$. [CrossRef]

233. Zhang, Y.; Kwon, S.; Yamaguchi, T.; Cubizolles, F.; Rousseaux, S.; Kneissel, M.; Cao, C.; Li, N.; Cheng, H.L.; Chua, K.; et al. Mice lacking histone deacetylase 6 have hyperacetylated tubulin but are viable and develop normally. Mol. Cell. Biol. 2008, 28, 1688-1701. [CrossRef] [PubMed]

234. Cantley, M.D.; Fairlie, D.P.; Bartold, P.M.; Marino, V.; Gupta, P.K.; Haynes, D.R. Inhibiting histone deacetylase 1 suppresses both inflammation and bone loss in arthritis. Rheumatology 2015, 54, 1713-1723. [CrossRef] [PubMed]

235. Kim, H.N.; Lee, J.H.; Bae, S.C.; Ryoo, H.M.; Kim, H.H.; Ha, H.; Lee, Z.H. Histone deacetylase inhibitor ms-275 stimulates bone formation in part by enhancing dhx36-mediated tnap transcription. J. Bone Min. Res. 2011, 26, 2161-2173. [CrossRef]

236. McGee-Lawrence, M.E.; Pierce, J.L.; Yu, K.; Culpepper, N.R.; Bradley, E.W.; Westendorf, J.J. Loss of hdac3 in osteoprogenitors increases bone expression of osteoprotegerin, improving systemic insulin sensitivity. J. Cell. Physiol. 2018, 233, 2671-2680. [CrossRef] [PubMed]

237. Blixt, N.C.; Faulkner, B.K.; Astleford, K.; Lelich, R.; Schering, J.; Spencer, E.; Gopalakrishnan, R.; Jensen, E.D.; Mansky, K.C. Class ii and iv hdacs function as inhibitors of osteoclast differentiation. PLoS ONE 2017, 12, e0185441. [CrossRef]

238. Li, H.; Xie, H.; Liu, W.; Hu, R.; Huang, B.; Tan, Y.F.; Xu, K.; Sheng, Z.F.; Zhou, H.D.; Wu, X.P.; et al. A novel microrna targeting hdac 5 regulates osteoblast differentiation in mice and contributes to primary osteoporosis in humans. J. Clin. Investig. 2009, 119, 3666-3677. [CrossRef]

239. Zhang, S.; Wu, W.; Jiao, G.; Li, C.; Liu, H. Mir-455-3p activates nrf2/are signaling via hdac2 and protects osteoblasts from oxidative stress. Int. J. Biol. Macromol. 2018, 107, 2094-2101. [CrossRef]

240. Ito, K.; Yamamura, S.; Essilfie-Quaye, S.; Cosio, B.; Ito, M.; Barnes, P.J.; Adcock, I.M. Histone deacetylase 2-mediated deacetylation of the glucocorticoid receptor enables nf-kappab suppression. J. Exp. Med. 2006, 203, 7-13. [CrossRef]

241. Dou, C.; Li, N.; Ding, N.; Liu, C.; Yang, X.; Kang, F.; Cao, Z.; Quan, H.; Hou, T.; Xu, J.; et al. Hdac2 regulates foxo1 during rankl-induced osteoclastogenesis. Am. J. Physiol. Cell Physiol. 2016, 310, C780-C787. [CrossRef]

242. Kim, D.S.; Kwon, J.E.; Lee, S.H.; Kim, E.K.; Ryu, J.G.; Jung, K.A.; Choi, J.W.; Park, M.J.; Moon, Y.M.; Park, S.H.; et al. Attenuation of rheumatoid inflammation by sodium butyrate through reciprocal targeting of hdac2 in osteoclasts and hdac8 in t cells. Front. Immunol. 2018, 9, 1525. [CrossRef] [PubMed]

243. McGee-Lawrence, M.E.; Bradley, E.W.; Dudakovic, A.; Carlson, S.W.; Ryan, Z.C.; Kumar, R.; Dadsetan, M.; Yaszemski, M.J.; Chen, Q.; An, K.N.; et al. Histone deacetylase 3 is required for maintenance of bone mass during aging. Bone 2013, 52, 296-307. [CrossRef]

244. Bradley, E.W.; Carpio, L.R.; Olson, E.N.; Westendorf, J.J. Histone deacetylase 7 (hdac7) suppresses chondrocyte proliferation and beta-catenin activity during endochondral ossification. J. Biol. Chem. 2015, 290, 118-126. [CrossRef]

245. Jin, Z.; Wei, W.; Dechow, P.C.; Wan, Y. Hdac7 inhibits osteoclastogenesis by reversing rankl-triggered beta-catenin switch. Mol. Endocrinol. 2013, 27, 325-335. [CrossRef] [PubMed] 
246. Pham, L.; Kaiser, B.; Romsa, A.; Schwarz, T.; Gopalakrishnan, R.; Jensen, E.D.; Mansky, K.C. Hdac3 and hdac7 have opposite effects on osteoclast differentiation. J. Biol. Chem. 2011, 286, 12056-12065. [CrossRef] [PubMed]

247. Jin, Z.; Wei, W.; Huynh, H.; Wan, Y. Hdac9 inhibits osteoclastogenesis via mutual suppression of ppargamma/rankl signaling. Mol. Endocrinol. 2015, 29, 730-738. [CrossRef] [PubMed]

248. Shakespear, M.R.; Hohenhaus, D.M.; Kelly, G.M.; Kamal, N.A.; Gupta, P.; Labzin, L.I.; Schroder, K.; Garceau, V.; Barbero, S.; Iyer, A.; et al. Histone deacetylase 7 promotes toll-like receptor 4-dependent proinflammatory gene expression in macrophages. J. Biol. Chem. 2013, 288, 25362-25374. [CrossRef] [PubMed]

249. Zhao, Y.X.; Wang, Y.S.; Cai, Q.Q.; Wang, J.Q.; Yao, W.T. Up-regulation of hdac9 promotes cell proliferation through suppressing p53 transcription in osteosarcoma. Int. J. Clin. Exp. Med. 2015, 8, 11818-11823.

250. Eckschlager, T.; Plch, J.; Stiborova, M.; Hrabeta, J. Histone deacetylase inhibitors as anticancer drugs. Int. J. Mol. Sci. 2017, 18, 1414. [CrossRef]

251. Li, Y.; Seto, E. Hdacs and hdac inhibitors in cancer development and therapy. Cold Spring Harb. Perspect. Med. 2016, 6, a026831. [CrossRef]

252. De Souza, C.; Chatterji, B.P. Hdac inhibitors as novel anti-cancer therapeutics. Recent Pat. Anticancer Drug Discov. 2015, 10, 145-162. [CrossRef] [PubMed]

253. West, A.C.; Johnstone, R.W. New and emerging hdac inhibitors for cancer treatment. J. Clin. Investig. 2014, 124, 30-39. [CrossRef]

254. Balemans, W.; Patel, N.; Ebeling, M.; Van Hul, E.; Wuyts, W.; Lacza, C.; Dioszegi, M.; Dikkers, F.G.; Hildering, P.; Willems, P.J.; et al. Identification of a $52 \mathrm{~kb}$ deletion downstream of the sost gene in patients with van buchem disease. J. Med. Genet. 2002, 39, 91-97. [CrossRef] [PubMed]

255. Balemans, W.; Ebeling, M.; Patel, N.; Van Hul, E.; Olson, P.; Dioszegi, M.; Lacza, C.; Wuyts, W.; Van Den Ende, J.; Willems, P.; et al. Increased bone density in sclerosteosis is due to the deficiency of a novel secreted protein (sost). Hum. Mol. Genet. 2001, 10, 537-543. [CrossRef] [PubMed]

256. Brunkow, M.E.; Gardner, J.C.; Van Ness, J.; Paeper, B.W.; Kovacevich, B.R.; Proll, S.; Skonier, J.E.; Zhao, L.; Sabo, P.J.; Fu, Y.; et al. Bone dysplasia sclerosteosis results from loss of the sost gene product, a novel cystine knot-containing protein. Am. J. Hum. Genet. 2001, 68, 577-589. [CrossRef] [PubMed]

257. Ellies, D.L.; Viviano, B.; McCarthy, J.; Rey, J.P.; Itasaki, N.; Saunders, S.; Krumlauf, R. Bone density ligand, sclerostin, directly interacts with lrp5 but not lrp5g171v to modulate wnt activity. J. Bone Min. Res. 2006, 21, 1738-1749. [CrossRef] [PubMed]

258. Wang, N.; Xue, P.; Wu, X.; Ma, J.; Wang, Y.; Li, Y. Role of sclerostin and dkk1 in bone remodeling in type 2 diabetic patients. Endocr. Res. 2018, 43, 29-38. [CrossRef]

259. Kamiya, N.; Ye, L.; Kobayashi, T.; Mochida, Y.; Yamauchi, M.; Kronenberg, H.M.; Feng, J.Q.; Mishina, Y. Bmp signaling negatively regulates bone mass through sclerostin by inhibiting the canonical wnt pathway. Development 2008, 135, 3801-3811. [CrossRef] [PubMed]

260. Biswas, S.; Li, P.; Wu, H.; Shafiquzzaman, M.; Murakami, S.; Schneider, M.D.; Mishina, Y.; Li, B.; Li, J. Bmpria is required for osteogenic differentiation and rankl expression in adult bone marrow mesenchymal stromal cells. Sci. Rep. 2018, 8, 8475. [CrossRef]

261. Liu, J.; Xu, K.; Wen, G.; Guo, H.; Li, S.; Wu, X.; Dai, R.; Sheng, Z.; Liao, E. Comparison of the effects of genistein and zoledronic acid on the bone loss in opg-deficient mice. Bone 2008, 42, 950-959. [CrossRef] [PubMed]

262. Moschen, A.R.; Kaser, A.; Stadlmann, S.; Millonig, G.; Kaser, S.; Muhllechner, P.; Habior, A.; Graziadei, I.; Vogel, W.; Tilg, H. The rankl/opg system and bone mineral density in patients with chronic liver disease. J. Hepatol. 2005, 43, 973-983. [CrossRef] [PubMed]

263. Garcia-Valdecasas-Campelo, E.; Gonzalez-Reimers, E.; Santolaria-Fernandez, F.; De la Vega-Prieto, M.J.; Milena-Abril, A.; Sanchez-Perez, M.J.; Martinez-Riera, A.; Gomez-Rodriguez Mde, L. Serum osteoprotegerin and rankl levels in chronic alcoholic liver disease. Alcohol Alcohol. 2006, 41, 261-266. [CrossRef] [PubMed]

264. Guanabens, N.; Enjuanes, A.; Alvarez, L.; Peris, P.; Caballeria, L.; Jesus Martinez de Osaba, M.; Cerda, D.; Monegal, A.; Pons, F.; Pares, A. High osteoprotegerin serum levels in primary biliary cirrhosis are associated with disease severity but not with the mrna gene expression in liver tissue. J. Bone Min. Metab. 2009, 27, 347-354. [CrossRef]

265. Monegal, A.; Navasa, M.; Peris, P.; Alvarez, L.; Pons, F.; Rodes, J.; Guanabens, N. Serum osteoprotegerin and its ligand in cirrhotic patients referred for orthotopic liver transplantation: Relationship with metabolic bone disease. Liver Int. 2007, 27, 492-497. [CrossRef] 
266. Fabrega, E.; Orive, A.; Garcia-Unzueta, M.; Amado, J.A.; Casafont, F.; Pons-Romero, F. Osteoprotegerin and receptor activator of nuclear factor-kappab ligand system in the early post-operative period of liver transplantation. Clin. Transpl. 2006, 20, 383-388. [CrossRef] [PubMed]

267. McClung, M.R. Denosumab for the treatment of osteoporosis. Osteoporos. Sarcopenia 2017, 3, 8-17. [CrossRef]

268. Zaheer, S.; LeBoff, M.; Lewiecki, E.M. Denosumab for the treatment of osteoporosis. Expert Opin. Drug Metab. Toxicol. 2015, 11, 461-470. [CrossRef]

269. Takeno, A.; Yamamoto, M.; Notsu, M.; Sugimoto, T. Administration of anti-receptor activator of nuclear factor-kappa $\mathrm{b}$ ligand (rankl) antibody for the treatment of osteoporosis was associated with amelioration of hepatitis in a female patient with growth hormone deficiency: A case report. BMC Endocr. Disord. 2016, 16, 66. [CrossRef] [PubMed]

270. Gonzalez-Reimers, E.; Martin-Gonzalez, C.; de la Vega-Prieto, M.J.; Pelazas-Gonzalez, R.; Fernandez-Rodriguez, C.; Lopez-Prieto, J.; Alvisa-Negrin, J.; Santolaria-Fernandez, F. Serum sclerostin in alcoholics: A pilot study. Alcohol Alcohol. 2013, 48, 278-282. [CrossRef] [PubMed]

271. Polyzos, S.A.; Anastasilakis, A.D.; Kountouras, J.; Makras, P.; Papatheodorou, A.; Kokkoris, P.; Sakellariou, G.T.; Terpos, E. Circulating sclerostin and dickkopf-1 levels in patients with nonalcoholic fatty liver disease. J. Bone Min. Metab. 2016, 34, 447-456. [CrossRef] [PubMed]

272. Gonzalez-Reimers, E.; Lopez-Prieto, J.; Pelazas-Gonzalez, R.; Aleman-Valls, M.R.; Jose de la Vega-Prieto, M.; Jorge-Ripper, C.; Duran-Castellon, M.C.; Santolaria-Fernandez, F. Serum sclerostin in hepatitis c virus infected patients. J. Bone Metab. 2014, 21, 69-75. [CrossRef]

273. Guanabens, N.; Ruiz-Gaspa, S.; Gifre, L.; Miquel, R.; Peris, P.; Monegal, A.; Dubrueil, M.; Arias, A.; Pares, A. Sclerostin expression in bile ducts of patients with chronic cholestasis may influence the bone disease in primary biliary cirrhosis. J. Bone Min. Res. 2016, 31, 1725-1733. [CrossRef] [PubMed]

274. Langdahl, B.L.; Libanati, C.; Crittenden, D.B.; Bolognese, M.A.; Brown, J.P.; Daizadeh, N.S.; Dokoupilova, E.; Engelke, K.; Finkelstein, J.S.; Genant, H.K.; et al. Romosozumab (sclerostin monoclonal antibody) versus teriparatide in postmenopausal women with osteoporosis transitioning from oral bisphosphonate therapy: A randomised, open-label, phase 3 trial. Lancet 2017, 390, 1585-1594. [CrossRef]

275. McClung, M.R. Sclerostin antibodies in osteoporosis: Latest evidence and therapeutic potential. Adv. Musculoskelet. Dis. 2017, 9, 263-270. [CrossRef] [PubMed]

(C) 2019 by the authors. Licensee MDPI, Basel, Switzerland. This article is an open access article distributed under the terms and conditions of the Creative Commons Attribution (CC BY) license (http://creativecommons.org/licenses/by/4.0/). 